\title{
Institutional diversity in domestic banking sectors and bank stability: A cross-country study*
}

\author{
Christopher F Baum (Boston College \& German Institute for Economic Research DIW Berlin) \\ Caterina Forti Grazzini (European Central Bank \& FU Berlin) \\ Dorothea Schäfer (German Institute for Economic Research DIW Berlin, JIBS \& CERBE) ${ }^{\dagger}$
}

This version: May 9, 2020

\begin{abstract}
This paper analyzes the causal relationship between institutional diversity in domestic banking sectors and bank stability. We use a large bank- and country-level unbalanced panel data set covering the EU member states' banking sectors between 1998 and 2014. Constructing two distinct indicators for measuring institutional diversity, we find that a high degree of institutional diversity in the domestic banking sector positively affects bank stability. The positive relationship between domestic institutional diversity and bank stability is stronger in times of crisis, providing evidence that diversity can help to absorb both financial and real shocks. In particular, greater institutional diversity smooths bank earnings risk in times of crisis. Our results are economically meaningful and offer important insights to the ongoing economic policy debate on how to reshape the architecture of the banking sector.
\end{abstract}

Keywords: Institutional Diversity; Shannon Index; Gini-Simpson Index; Bank Stability; Financial Crisis; Bank Competition

JEL: G01, G20, G21, G28

\footnotetext{
${ }^{*}$ We thank participants of the research seminar of School of Economics and Business Administration, University Jena, the 2019-Annual Meeting of the German Economic Association in Leipzig and the workshop European banking landscape between diversity, competition and concentration in Berlin for their helpful comments and suggestion. The opinions in this paper are those of the authors and do not necessarily reflect the views of the European Central Bank or of the Eurosystem. Schäfer gratefully acknowledges a research grant from the Wissenschaftsförderung der Sparkassen-Finanzgruppe. The usual disclaimer applies.

${ }^{\dagger}$ Corresponding author: dschaefer@diw.de, Mohrenstrasse 58, 10117 Berlin Germany
} 
... excessive homogeneity within a financial system - all the banks doing the same thing can minimize risk for each individual bank, but maximize the probability of the entire system collapsing.

Andrew G. Haldane Robert M. May

\section{Introduction}

The Lehman Brothers collapse in 2008 and the successive global financial turmoil reminded us that individual banks and complete financial systems can turn from stable into unstable literally overnight. The question of what makes banks more resilient is thus ultimately important. There is an increasing interest in the role of institutional diversity in domestic banking sectors and how this affects bank stability. However, we know little about institutional diversity and its effects on banks, despite the prominent role this issue played in the economic policy debate during the financial crisis (e.g. Boot 2014, De Nederlandsche Bank N.V., 2015, Dimon 2016, Haldane 2009, Haldane \& May 2011). So far, the debate on financial systems' role in bank stability across countries has been centered around the capability of market-based vìs-à-vìs bank-based financial systems to absorb shocks (see e.g. Baum et al. 2011 and Levine 2002). Accordingly, the recent debate on European Capital Markets Union focuses on the interaction between market-based and bank-based elements, but ignores the potential benefits and costs of having a diverse collection of banks in the financial sector. This stands in contrast to the emphasis placed by the European Commission on the benefits of diverse industrial structures ${ }^{1}$

The banking sector is the most important part of the financial system in most EU member states and the key financing source for SMEs, which account for about 99 percent of EU firms (European Banking Authority|2016). Focusing on the simple dichotomy between marketoriented and bank-oriented financial systems (Beck, Demirgüc-Kunt \& Singer 2013, Langfield

\begin{tabular}{l}
\hline${ }^{1}$ E.g. Speech by Margrethe Vestager, EU Commission, November 20,2018, \\
$\begin{array}{l}\text { And that diverse collection of businesses - like a healthy, varied ecosystem in the natural world - can } \\
\text { help to keep our economy strong and resilient. }\end{array}$ \\
https://ec.europa.eu/commission/commissioners/2014-2019/vestager/announcements/ \\
\hline strength-diversity_en
\end{tabular}


\& Pagano 2016. Gambacorta et al. 2014) shows only one side of the coin. We also need robust evidence on the other side: whether institutional diversity within the domestic banking sector can mitigate the impact of shocks during a financial crisis.

Our main objective in this study is to present data-driven evidence on the question of whether distinct levels of institutional diversity in EU countries' banking sectors matter for individual bank stability. Does a diversity-bank stability nexus exist, in the sense that higher institutional diversity shields the banks better from the adverse impact of an idiosyncratic shock? The theory behind the assumed nexus rests upon the principle of diversification. With only one business model or bank type, the performance of the sector may be closely tied to the performance of that business model or type. When the core business model is suffering from an economic slump, the lack of institutional diversity could become a threat to individual banks' stability and, via contagion, to the entire financial sector. Having a collection of bank types and a variety of business models may lower the likelihood of contagion and reduce the risk for individual banks of being affected.

We explore this conjecture using a sample of European banks headquartered in EU member countries over the period 1998-2014. The pre-crisis period covers the years until 2006, while the years 2007-2014 mark the crisis period. Empirical identification of the structural diversity effect is challenging. To meet that challenge, we apply established panel data estimation techniques borrowed from the competition-bank stability literature (Berger et al. 2008, Beck, Jonghe \& Schepens 2013). To capture the extent to which the collection of banks in the sector is diverse we apply the two most popular diversity concepts: the Shannon and the Gini-Simpson indices (Shannon 1948, Simpson 1949).

Diversity and competition are often used as quasi-synonyms although evidence backing this notion is lacking. To gain better insights into the diversity-competition puzzle we aim to disentangle the diversity channel from the competition channel via the inclusion of the Lerner index in the analysis as a proxy for competition. As is well known, the Lerner index measures only one dimension of competition: the individual bank's price setting power. Price setting power is definitely low if bank competition is extensive, but is not necessarily low if the diversity of the financial sector is high. Thus, including the Lerner index does not exclude the 
possibility that other dimensions of competition, such as the absence of too-big-to-fail advantages (Ueda \& di Mauro|2013) or contestability (Brock|1983, Schaeck \& Cihàk|2014, Goetz|2018) may still be partly captured by the diversity indicators.

Our analysis reveals two main results. Institutional diversity in the domestic banking sector positively affects individual bank stability, and their impact appears to be stronger in times of crisis. This finding confirms a priori expectations about a greater shock absorbing capacity in a more instutionally diverse banking sector. The direction of the diversity-stability relationship depends on bank specialization, with savings and cooperative banks benefiting more in terms of stability than commercial banks. A higher Lerner Index has a positive impact on bank stability, implying that institutional diversity is more than just individual banks' low levels of price setting power.

We contribute to the literature in several ways. First, we enrich the research on important characteristics of financial systems by identifying institutional diversity as an important characteristic beyond the simple dichotomy of bank-based vìs-à-vìs market-based financial systems. Second, we apply measures of institutional diversity that have been rarely employed in the prior literature on banking systems. Finally, we fill a gap in the literature by quantifying the impact of institutional diversity on individual bank stability in both crisis and non-crisis times.

The reminder of this paper is organized as follows. Section 2 reviews the diversity-stability nexus. Section 3 presents the data and Section 4 describes the empirical strategy and the results. Section 5 presents robustness checks, while Section 6 concludes.

\section{The Diversity-Stability Nexus}

Previous research proposes two channels through which the domestic banking sector's degree of institutional diversity could affect bank stability. One channel is diversification. Two concepts of diversification are used in the literature: diversification across bank types and intrabank diversification. Diversification across distinct bank types suggests that uniformity is far less desirable than a mixture of different bank types in the sector (Haldane 2009). A few pioneering studies argue that a diverse banking sector will have a better chance of remaining stable throughout turbulent times because less affected bank types may be able to compensate 
for the distorted deposit and credit flows in heavily affected bank types (see Ayadi et al. 2009. 2010 and Haldane \& May 2011).

In contrast, intrabank diversification refers to bank expansion into new lines of business, new branches, and new countries. This type of diversification is closely tied to bank size. The more banks expand across financial product lines and countries, the larger they become. Such developments may reflect economies of scale and gains in efficiency and earn a diversification premium (Baele et al. 2007). On the other hand, monitoring efficiency is likely to suffer when a large number of diverse, weakly-linked business activities are involved (e.g. Acharya et al. 2006, Stiroh \& Rumble 2006, Laeven \& Levine 2007). If intrabank diversification strategies are similar, banks may not only become larger but more closely resemble each other in taking on the same type of risks. Systemic risk rises as the likelihood increases that, in a crisis, all banks are hit in the same way and credit and deposit flows are distorted in the whole economy. From this perspective, there is a trade-off between intrabank diversification and between-bank diversity.

The second channel through which institutional diversity within the banking sector may affect bank stability is competition. The more distinct types of large, medium, and small banks, with different business models co-exist, the more intense the competition within the sector may be (Ayadi et al. 2009, 2010). The implications of higher competition for SME lending and bank stability is widely debated. One strand of literature proposes that a more competitive and less concentrated banking system is more fragile and less stable (Beck et al.|2005, Berger et al. 2008, Beck, Jonghe \& Schepens 2013). In contrast, based on microdata of banks in different regions of Kazakhstan from 2004, Schäfer et al. (2010) show that greater competition increases SME lending in an emerging economy. Schaeck et al. (2009) reveal that the threat of market entry and increased competition could stimulate firms' innovation and encourage banks' efficiency by keeping loan rates low. Both have beneficial effects for financial stability, while 'too big to fail' banks, with implicit government guarantees, are likely to take excessive risks, thus potentially endangering stability. Schaeck \& Cihàk (2014) use a panel dataset for European banks $\left.\right|^{2}$ covering the period 1995-2005 and a cross-sectional sample of banks operating in rural

\footnotetext{
${ }^{2}$ Their analysis covers banks from Austria, Belgium, Denmark, France, Italy, Germany, Luxembourg, the Nether-
} 
counties in the US in 2005. They reveal that competition increases banks' efficiency. Akins et al. (2016) use data for banks from all US states during the period 2000-2010. They find that higher competition has a disciplining effect in the sense that it is associated with lower risk-taking by banks and higher mortgage rejection rates ${ }^{3}$ Such behavior would make banks less likely to suffer from credit losses implying greater stability. Goetz (2018) finds that increased market contestability improves bank stability.

Despite the assumed link between institutional diversity and competition, we know surprisingly little about the true relationship between those two structural characteristics. High institutional diversity may not necessarily imply that banks lack price setting power. For example, a bank focusing on financing local firms may enjoy a high price-setting power in the local banking market despite high institutional diversity at the country level. To account for possibly distinct effects of institutional diversity and competition we include the individual bank's Lerner index as a proxy for competitiveness in the estimation (Beck, Jonghe \& Schepens 2013).

\subsection{Institutional diversity: Is there a crisis dividend?}

A crucial channel for banks seeking to strengthen their resilience is investment in assets yielding stable returns and accessing stable sources of funding. Of course, this strategy has its own cost as it requires banks to sacrifice both investing in high-risk, high-return assets and exploiting cheap short-term funding sources, e.g., 'hot money' from capital markets. Low institutional diversity may imply that a high share of bank assets is concentrated in 'too-big-to-fail' banks. Such banks enjoying implicit government guarantees may be particularly prone to excessive risk-taking (Gropp et al. 2014). High asset and loan growth in banks with significant market power may go hand in hand with less strict lending standards and/or a shift towards investments in securities with high but very risky returns, and a higher reliance on cheap short-term capital market funding that must be rolled over on a regular basis. Low monitoring and screening efforts also affect medium-sized and smaller banks in the sector (Köhler 2015).

In good times banks enjoy the upside potential resulting from low funding costs and high lands, Switzerland, and the United Kingdom.

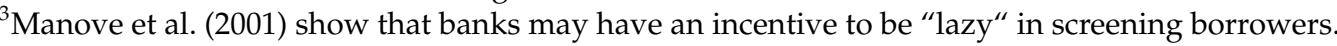


investment returns (Baum et al. 2009). However, when a crisis hits, those banks suddenly face the downside risk of lax investment standards and short-term funding shortfalls (Segura \& Suarez 2017), and their behavior is likely to become more homogeneous. Difficulties in rolling over short-term funding forces banks to rely on more expensive funding sources, and may even require detrimental fire sales if short-term funds are scarce in the entire financial sector. In addition, funding-constrained banks tend to constrain their lending (Jasova et al.|2018), which coerces existing borrowers to turn to other funding sources and may exclude potential clients from access to funding. The fewer lenders exist and the more similar their lending policies are the more difficult it will be for borrowers to deal with reductions in loan limits or cancellation of letters of credit. Therefore, liquidity constraints may force more firms and households into financial stress, threatening borrowers' debt service (Hubert \& Schaefer|2002). At this point the banking crisis turns into an economic crisis, threatening earnings across the financial sector.

A financial crisis threatens banks' stability and, with some delay, may influence the degree of institutional diversity in the banking sector. Struggling banks are often rescued by means of a merger with a stronger bank. In addition, regulatory changes implemented to extinguish the driving forces behind the crisis often impose disproportionately high compliance costs on smaller banks. Thus, there is increased pressure for small banks to merge into larger units or even to leave the market. Accordingly, a financial crisis could be associated with a reduction in banking sector diversity. On the other hand, if large banks are particularly affected, regulators may apply pressure to shrink their balance sheets and narrow their lines of business, potentially increasing institutional diversity in the banking sector.

We hypothesize that institutional diversity is a kind of insurance mechanism particularly valuable in financial turmoil. It insures banks and the economy to some extent against the risk of common shocks to the banking sector due to their homogenous behavior and highly correlated risk. When a financial crisis hits, individual banks' stability should benefit from a more institutionally diverse banking sector. In the following sections we examine whether this proposition holds for the domestic banking sectors in the European Union. 


\section{Data}

\subsection{Data sources}

We obtain bank-level data from the Fitch/Bureau Van Dijk Bankscope, a database that gathers information on balance sheets and income statements of listed financial institutions worldwide. We combine it with country-level variables from the World Bank's Global Financial Development Database. Our sample covers 22 member states of the European Union over the 1998-2014 period ${ }^{4}$ Focusing on EU countries has the advantage that credit market conditions and bank regulation are fairly similar, and, thus, are unlikely to bias the estimation results on the link between institutional diversity and bank stability.

In order to clean and prepare the dataset, we follow the methodology proposed by Duprey \& Lè (2016). The database contains unconsolidated as well as consolidated bank balance sheets from the same bank. To avoid double counting, we keep only consolidated data when available. Moreover, our sample is free of survivorship bias as we also include banks that were delisted in the period under analysis. All variables in levels have been converted to US dollars using the exchange rates provided by Bankscope. Finally, we exclude banks with fewer than 50 observations and we drop observations if they provide unreliable indicator values $5^{5}$ We focus on commercial, cooperative and savings banks, which comprise more than $88 \%$ of all included banks. The final sample includes 38,729 bank-year observations (see Table 5).

\subsection{Measuring institutional diversity in the domestic banking sector}

In order to test for the diversity-stability nexus we need a quantitative measure for institutional diversity in the domestic banking sector. We construct two indicators. The first one, FinStruct, exploits the heterogeneity in the distribution of the three banking groups (commercial, cooperative and savings banks) across different years and EU member states. Its construction follows

\footnotetext{
${ }^{4}$ Those are Austria, Belgium, Bulgaria, Croatia, Cyprus, Denmark, Finland, France, Germany, Greece, Ireland, Italy, Latvia, Lithuania, Netherlands, Portugal, Romania, Slovak Republic, Slovenia, Spain, Sweden and United Kingdom. The Czech Republic, Estonia, Hungary, Luxembourg, Malta and Poland have been dropped due to inadequate coverage.

${ }^{5}$ Observations are dropped if (net) loans over total assets, equity over assets and deposits over total assets are greater than 1 or if total assets, equity or loans are negative.
} 
the Shannon index (Shannon 1948),

$$
\text { FinStruct }_{c, t}=-\sum_{j=1}^{J} S_{j, c, t} \ln S_{j, c, t} \in[0, \ln (J)]
$$

where $S_{j c t}$ denotes the share of group $j^{\prime}$ s total assets over country's $c$ total banking sector assets in year $t ; j=[1,2,3]$. FinStruct quantifies the uncertainty in predicting the group identity of a bank that is taken at random from the dataset. This uncertainty is maximal if each bank type has the same chance of appearing. In other words, if the country's banking sector assets are equally distributed across the $J$ distinct bank types, then FinStruct $t_{c, t}$ would achieve the maximal value of $\ln (J)$.

The second measure of institutional diversity, FinDivers, builds on the notion that banking systems are more diverse if their concentration is lower. Diversity is the lowest if the multitude of distinct financial services required in the economy is concentrated in one huge bank, and it is the highest if the distinct financial services required in an economy are evenly spread across a large number of small banks. Accordingly, we use the Gini-Simpson concept (Simpson 1949) which exploits the country-level heterogeneity in the number and size of banks. With the individual bank $i$ 's share, $S_{i c t}$, in the domestic banking sector assets

$$
\text { FinDivers }_{c, t}=1-\sum_{i=1}^{N}\left(S_{i, c, t}\right)^{2} .
$$

FinDivers is zero if the country's banking sector comprises only one bank $\left.\right|^{6}$ The maximal value of FinDivers is $(N-1) / N$ meaning that FinDivers increases with the number $N$ of banks in a country, and, for a given $N$, with a more even size distribution. $7^{7}$

In line with (Haldane \& May 2011) we hypothesize that institutional diversity will enhance bank stability by shielding the domestic banking sector to some extent from the adverse impact

\footnotetext{
${ }^{6}$ The Gini-Simpson index is 1-Herfindahl index.

${ }^{7}$ The Shannon diversity measure, FinStruc, is equal to the logarithm of 1 minus the weighted arithmetic mean of the logarithm for the probability of a specific type where the weights are the probabilities themselves. With $S_{j}$ as the proportion of type $j$ assets (e.g. $j \in$ [Commercial, Savings, Cooperative]) in the country's aggregated bank assets,

$$
\text { FinStruct }=\ln 1-\left(\ln S_{1}^{S_{1}}+\ln S_{2}^{S_{2}}+\ldots . .+\ln S_{J}^{S_{J}}\right)=-\left(S_{1} \ln S_{1}+S_{2} \ln S_{2}+\ldots . .+S_{J} \ln S_{J}\right) .
$$

The Gini-Simpson diversity indicator, FinDivers, equals 1 minus the weighted arithmetic mean of the probability of a specific type where the weights are the probabilities themselves,

$$
\text { FinDivers }=1-\left(S_{1} S_{1}+S_{2} S_{2}+\ldots .+S_{N} S_{N}\right),
$$

with FinDivers index $\in\left[0,1-\frac{1}{N}\right]$. In essence, since the logarithm of a small fraction becomes very large in absolute value, the Shannon concept values the occurrence of rare types more heavily than the Gini-Simpson concept.
} 
of idiosyncratic shocks. With only one bank type the performance of the sector is dominated and thus closely tied to the performance of that type. This may become a threat to the stability of each bank and to the entire sector if this particular bank type suffers from an economic slump. During booms, the specific bank type may flourish. Institutional diversity would then potentially serve as a drag on the banking sector's economic prospects that could otherwise grow more rapidly if the sector only consists of the bank type most sensitive to economic conditions. The real benefit of having an institutionally diverse banking sector may become evident during times of crisis, in which a banking system dependent on one bank type may be hardest hit.

\subsection{Measuring bank stability}

We use the Z-score to measure bank stability (e.g., see Leroy \& Lucotte 2017, Goetz 2018, Beck, Jonghe \& Schepens 2013, Schaeck \& Cihàk 2014, Berger et al. 2008). 8 The Z-Score indicates how much variability in returns can be absorbed by capital plus current net profits without the bank becoming insolvent ( $\mathrm{Li} \&$ Malone 2016).9 ${ }^{9}$ A higher Z-score implies a larger distance from insolvency and greater financial stability for the individual bank. The Z-score is calculated as

Note that both diversity indicators are special cases of the general function

$$
\operatorname{DIV}(\mathrm{q})=\left(\sum_{1}^{K} p_{k}^{q}\right)^{\frac{1}{1-q}}
$$

with $p_{k}$ as the proportion of type $i$ in the overall population of a specific entity, $K$ as the number of different types and $q$ measuring the sensitivity to rare types. If $q$ approaches 1 this yields

$$
\begin{aligned}
\text { Shannon Index } & =\ln \lim _{q \rightarrow 1} \operatorname{DIV}(q)=\ln e^{-\sum_{1}^{K} p_{k} \ln p_{k}} \\
& =-\sum_{1}^{K} p_{k} \ln p_{k}=-\ln p_{1}^{p_{1}} p_{2}^{p_{2}} p_{3}^{p_{3}} \ldots . . p_{K}^{p_{K}}=\ln \frac{1}{\Pi_{1}^{K} p_{k}^{p_{k}}} .
\end{aligned}
$$

Inserting $q=2$ into Equation (1) and rearranging yields

$$
\text { Gini-Simpson Index }=1-\frac{1}{\operatorname{DIV}(q)}=1-\sum_{1}^{K} p_{k}^{2} .
$$

\footnotetext{
${ }^{8}$ The majority of banks in the European Union are not listed on a stock exchange and, hence, using market-based indicators for the banks' risk taking, such as S-Risk or CoVar are only available at the cost of a much smaller sample (Gehrig \& Iannino 2017, Adrian \& Brunnermeier 2016). 2019).

${ }^{9}$ The Z-score can be interpreted as the probability that the bank losses exhaust the bank's equity (Pino \& Sharma
} 
follows:

$$
\mathrm{Z}_{- \text {Score }_{i, t}}=\frac{\left(R O A_{i, t}+\frac{\text { Equity }_{i, t}}{\text { Assets }_{i, t}}\right)}{\sigma(R O A)}
$$

where $R O A$ is the return on assets for bank $i$ at time $t, \frac{E q u i t y_{i, t}}{\text { Assets }_{i, t}}$ is the equity to assets ratio and $\sigma(R O A)$ is the standard deviation of $R O A$ over a rolling window of 3 years in the main specification and 5 years in the robustness check. The rolling time window is used to dampen fluctuations in the Z-Score that are exclusively driven by variation in the levels of profitability and capital (Schaeck \& Cihàk|2014).

\subsection{Measuring market power}

Many studies find that competition is an important determinant of banks' stability (Claessens \& Laeven 2004, Goetz 2018, Schaeck et al. 2009, Beck, Jonghe \& Schepens 2013). Others emphasize that competition could be the channel through which institutional diversity affects stability (Ayadi et al.2009, 2010). In order to disentangle the diversity effect from the competition effect we include the Lerner index of monopoly power as a control variable in all model specifications (Beck, Jonghe \& Schepens 2013). A clear advantage of the Lerner index is that it can be measured both at the bank level and over time, so it can identify different patterns of behavior within the same market and/or between years. Moreover, it does not require a clear definition of the geographical market of the bank. The Lerner index (Lerner|1934) for each bank and year is calculated as the difference between actual price $P_{i, t}$ and marginal $\operatorname{cost} M C_{i, t}$, divided by price $P_{i, t}$ :

$$
\text { Lerner Index } i_{i, t}=\frac{P_{i, t}-M C_{i, t}}{P_{i, t}} .
$$

The index captures the deviation of the price charged by a firm in a normal market from the price that would emerge in case of perfect competition. Under standard assumptions, the index should rise as a firm's market power increases and converge to zero as competition intensifies and the price falls 10 We follow Beck, Jonghe \& Schepens (2013) in estimating the marginal cost. The total operating cost of running a bank is expressed as a translog function of a single

\footnotetext{
${ }^{10}$ Contrary to theory, in reality it might be possible for the price to fall below marginal cost for a brief period.
} 
aggregate output proxy, $Q_{i, t}$ and three input prices, $w_{i, t}^{j}, j \in(1,2,3)$. Thus, we estimate

$$
\begin{aligned}
\ln \mathrm{C}_{i, t}= & \alpha_{0}+\alpha_{1}\left(\ln \mathrm{Q}_{i, t}\right)^{2}+\sum_{j=1}^{3} \beta_{j} \ln \mathrm{w}_{i, t}^{j}+\sum_{j=1}^{3} \sum_{k=1}^{3} \beta_{j, k} \ln \mathrm{w}_{i, t}^{j} \ln \mathrm{w}_{i, t}^{k} \\
& +\sum_{j=1}^{3} \gamma_{j} \ln \mathrm{w}_{i, t}^{j} \ln \mathrm{Q}_{i, t}+v_{t}+\epsilon_{i, t}
\end{aligned}
$$

where $C_{i, t}$ measures total operating cost (interest expenses, personnel and other administrative or operating costs) and $Q_{i, t}$ is a proxy for bank output or total assets for bank $i$ at time $t$. The three input prices $w$ capture the price of fixed factors $\left(w_{1}\right)$, the price of labor $\left(w_{2}\right)$ and the price of borrowed funds $\left(w_{3}\right)$. They are, respectively, the share of other operating and administrative expenses to total assets, the ratio of personnel expenses to total assets and the ratio of interest expenses to total deposit and money market funding. The cost function is estimated separately for each country in order to account for potentially different technologies. Moreover, we also include time dummies to capture technological progress and the business cycle. Homogeneity of degree one in input prices is obtained by imposing the restrictions: $\sum_{j=1}^{3} \beta_{j}=1, \sum_{j=1}^{3} \gamma_{j}=0$ and $\forall k \in(1,2,3): \sum_{j=1}^{3} \beta_{j, k}=0$. The marginal cost is then obtained as follows

$$
M C_{i, t}=\frac{\partial C_{i, t}}{\partial Q_{i, t}}=\frac{C_{i, t}}{Q_{i, t}}=\hat{\alpha}_{1}+2 \hat{\alpha}_{2} \ln Q_{i, t}+\sum_{j=1}^{2} \hat{\gamma}_{j} \ln \frac{w_{i, t}^{j}}{w_{i, t}^{3}}
$$

\subsection{Other bank and country-level variables}

We add several control variables to complete the model specification. Following Laeven \& Levine (2007) we use the share of non-interest income over total income (Internal Divers) as control variable indicating intrabank diversification. A priori, this variable's influence on bank stability is undetermined. On the one hand, theory suggests that internal diversification may enable banks to exploit economies of scale and scope, earning a diversification premium. On the other hand, highly diversified banks may lose monitoring efficiency. In addition, herding behavior in diversifying internally may generate extremely similar bank types all exposed to the same risk. Laeven \& Levine (2007) find a substantial diversification discount and conclude that the benefits of internal diversification are insufficient to compensate for the costs. Schmid \& Walter (2009) find for US banks observed between 1985-2004 that functional diversification 
within a bank destroys firm value. In contrast, Baele et al. (2007) report an internal diversification premium on the franchise value of European banks between 1998-2004. Analysing a sample of listed banks from 35 countries, Guerry \& Wallmeier (2017) provide evidence that the discount of internal diversification on Tobin's $Q$ has decreased over time and vanished in the years 2007-2013.

Efficiency is a related bank-level characteristic but capable of separately influencing bank stability. We use the cost to income ratio as a proxy for Efficiency and expect a negative sign on the respective coefficient. The share of wholesale funding in total funding, Wholesale Funding, indicates the individual bank's funding structure. Most of the pre-crisis literature would point to the benefits derived from the use of market financing to raise sizable low cost funding in the interbank markets. Moreover, compared to depositors, financial market investors were expected to provide more market discipline (Calomiris \& Kahn 1991) and to refinance unexpected retail withdrawals (Goodfriend \& King 1988). The recent financial crisis, however, has shown the dark side of wholesale funding: not only do wholesale financiers have lower incentives to conduct costly monitoring (Huang \& Ratnovski|2011), but some research suggests that in times when funding from financial markets is scarce and costly, the market values of those institutions primarily funded via customers' deposits respond positively (Beltratti \& Stulz 2012).

To indicate the bank's Liquidity status we use the share of liquid assets over total assets. Once again the literature on the relationship between bank stability and liquidity is inconclusive. On the one hand, high liquidity buffers make banks less vulnerable to funding shocks and reduce the risks embedded in banks' intermediation. On the other hand, liquidity might reduce the bank's returns and hamper stability (König 2015). Higher liquidity may increase risk-taking as banks may change their behavior as a result of the increased liquidity of their assets (Wagner 2007). This can lead to contagion because it facilitates mutual credit exposures (Freixas et al. 2000) and creates spillovers across banks (Aghion et al. 2000). Accordingly, the effect of Liquidity on banks' stability cannot be signed.

The variable Equity over Liabilities controls for the bank's leverage and level of capitalization 11 If a bank improves capitalization, bank stability should increase. In addition, we in-

\footnotetext{
${ }^{11}$ See Moudud-Ul-Huq (2019) for an impact of crisis on banks' capital buffers, risk and efficiency.
} 
clude NetIncome over assets as proxy for the bank's net earning power expecting that a high net earning power contributes positively to stability (Beck et al. 2006, Cihák \& Schaeck 2007). The natural logarithm of total assets (Size) and the growth ratio (Asset Growth) control for bank size and growth, respectively. Size can be an important determinant of banking sector risk (Huang \& Ratnovski 2011, Drehmann \& Tarashev 2013) but the effect of size on bank stability is a-priori unclear. Larger banks' lending strategies are more likely to be based on hard information, while small banks often rely more heavily on soft information such as relationship lending, which may benefit lenders in crisis times (Banerjee et al.|2017). Larger banks may enjoy higher implicit guarantees to be rescued by the sovereign in case of failure. This implicit protection provides superior credit ratings and more favorable financing conditions (Ueda \& di Mauro 2013) that are in principle stability-enhancing. However, the adverse incentives arising from systemic significance (Demirgüç-Kunt \& Huizinga 2010) must be recognized. Banks that are "too big to fail" may pursue risky lending strategies knowing that the state will be forced to bail them out (Hoerova et al.|2018, Langfield \& Pagano|2016).

At the country level, we control for Sector Size (the ratio of deposit money banks' assets to GDP), Financial Depth (the ratio of private credit by deposit money banks to GDP) and Credit to MarketCap (the ratio of private credit by deposit money banks to market capitalization). Sector Size represents the relative size of the country's banking sector to the size of the economy. Financial Depth measures the importance of bank lending relative to GDP and Credit to MarketCap relative to the market value of listed companies' shares. In addition, we include Inflation as a control for macroeconomic risk that is likely to affect the banking sector. Inflation may support banks to ease the own debt burden but, on the other hand, may increase a bank's investment risk and deflate the values of long-term assets. The coefficient's sign is thus undetermined. Table 1 in the Appendix presents a detailed list of the variables employed in the analysis and the sources from which they are collected.

The proposed effects of the bank-level and country-level variables are summarized in Table 3. The first column represent the variables of interest while the second reports their expected impact on bank stability. Table 4 and Figures 1 - -4 provide and illustrate descriptive statistics. 


\subsection{Descriptive Statistics}

Figure 1 shows the distribution of institutional diversity in the domestic banking sector at the country-year level proxied with FinStruct (left panel) and FinDivers (right panel). For the construction of these graphs, the country-year pairs are not weighted by the number of bank observations per country-year. In roughly $13 \%$ of the country-year observations FinStruct is equal to 0 , indicating the presence of only one bank type (commercial banks) in that country and year. The remaining observations indicate the presence of higher levels of institutional diversity, with two bunchings around 0.1 and 0.6 . The graph also shows that fewer than $1 \%$ of the country-year combinations of institutional diversity are above 1, nearing the maximal level of FinStruct is $\max ($ FinStruc $)=\ln 3=1.099$. In the right panel the mass of observations is concentrated to the right. In particular, there is no country-year pair value above 0.99 , indicating that there is no banking system that can be defined highly diverse. Roughly $50 \%$ of the observations are above 0.85 , indicating a diverse domestic banking sector. $30 \%$ of the observations are above 0.75 and below 0.85 and can be classified as moderately diverse. The remaining observations are classified as indicating low diversity ${ }^{12}$

Figure 2 shows the evolution over time of the two main variables of interest, FinStructand FinDivers, and of the Z-Score measures employed in the analysis. With respect to the two latter variables, they are first averaged by country and then across countries, to give equal weight to each country. The values of the institutional diversity indicators are measured at the righthand axis, while the values of the Z-Scores are visible on the left-hand axis. The grey dashed line highlights the year 2007, which we take as reference year for the crisis period. There is a close correspondence between the time series pattern of bank stability (Z-Scores) and diversity proxied by FinStruct, which indicates that diversity and bank soundness are positively correlated over time. Moreover, the Figure also shows that, although there is evidence of a general positive trend between 1998 and 2014, it appears that in the second half of the sample FinStruct has grown faster than in the first half. On the other hand, there is no evidence of correlation between bank soundness and FinDivers. The evolution over time at the country level of the

\footnotetext{
12 This classification relies on the traditional classification of the $\mathrm{HHI}$ index. In particular, a $\mathrm{HHI}<0.01$ indicates a highly competitive industry; an $\mathrm{HHI}<0.15$ indicates an unconcentrated industry; an $0.15<\mathrm{HHI}<0.25$ indicates moderate concentration, while $\mathrm{HHI}>0.25$ indicates high concentration.
} 
two diversity indicators and of the two bank stability measures can be found in Figures 3 and 4. respectively.

\section{Empirical analysis}

\subsection{Model}

In order to examine how institutional diversity in the domestic banking sector affects bank stability, we use a causal inference technique similar to a difference-in-differences (DID) approach. We construct a combined model to reflect differences across groups (bank types) and time periods (pre-crisis and crisis period). In particular, we interact all bank-level and country-level variables with BankType, a categorical variable indicating whether a bank is cooperative, saving or commercial, and with Post2007, a dummy variable equal to 1 if year $\geq 2007$ (crisis period) and zero otherwise.

$$
\text { Z-Score }_{i, c, t}=\alpha_{i}+\left(\beta_{1} D I V_{c, t}+\beta_{2} X_{i, c, t-1}+\beta_{3} Z_{c, t}\right) * \text { BankType } * \text { Post } 2007+\gamma_{t}+\epsilon_{i, c, t} .
$$

The specification estimates marginal effects which differ for every covariate by BankType and Post2007. The Z-Score $3_{i, c, t}$ is calculated using a 3-year rolling standard deviation of ROA. The indices $i, c, t$ stand respectively for bank, country and time. We alternatively employ two distinct diversity measures: $D I V_{c, t} \in\left[\right.$ FinStruct $_{c, t}$, FinDivers $\left._{c, t}\right]$; their construction is explained in Subsection 3.2. Z-Score $3_{i, c, t}$ and the two diversity indicators are standardized ${ }^{13} X_{i, c, t-1}$ is a vector including bank-specific characteristics, lagged to account for endogeneity concerns. $Z_{c, t}$ contains macro-level explanatory variables likely to affect bank stability (see Subsection 3.5), while $\alpha_{i}$ and $\gamma_{t}$ are the bank and time fixed effects. Finally, $\epsilon_{i, c, t}$ is an idiosyncratic error term assumed to satisfy the usual assumptions, clustered at the country-year level.

Each combination of BankType and Post2007 defines a subgroup. The estimated marginal effects represent, for each subgroup,

$$
\frac{\partial \text { Z-Score } 3_{i, c, t}}{\partial V} \text { with } V \in\left[D I V_{c, t}, X_{i, c, t-1}, Z_{c, t}\right] .
$$

We obtain the Average Marginal Effect (AME) for FinStruct, FinDivers, and the other covariates by evaluating for each observation the resulting $\varepsilon$-change in the dependent variable, computing

\footnotetext{
${ }^{13}$ In addition to dependent variable and diversity indicators, the Lerner Index, Equity over Liabilities and Net Income over Assets are standardized.
} 
the derivative of Z-Score3 with respect to the covariates and then averaging over observations. This approach allows us to compare the before-and-after and between-bank-types difference in the response to a marginal change in the institutional diversity indicator $D I V_{c, t}$. It is thus not a classical difference-in-differences approach but is a generalized DID model which allows us to partial off the effect of the financial crisis from the effect of institutional diversity in the banking sector. We can then test whether those conditional effects are statistically distinguishable.

\subsection{Results}

\subsubsection{Baseline Results}

Table 5 reports the baseline regression results for FinStruct (Columns (1) to (3)) and FinDivers (Columns (4) to (6)). The Columns (1) and (4) report the marginal effects for the full sample. The Columns (2) and (5) show the coefficients for the pre-crisis subsample (from 1998-2006), and the Columns (3) and (6) for the crisis subsample (from 2007-2014). The Table shows a positive and significant relationship between institutional diversity and bank stability. In crisis times, the sign and significance of the coefficients are consistent over both diversity measures, implying that different dimensions of diversity are relevant for bank stability. The effects are stronger in the post-2007 period (Column (3) and (6)), suggesting that institutional diversity is especially important in crisis periods. The estimated effects are not only statistically significant but meaningful in economic terms. For example, in the years 2007-2014, a one standard deviation increase in FinStruct and FinDivers induces an average marginal increase of 0.247 and 0.0781 standard deviations in the Z-score3, respectively. Those findings support the conjecture that the real benefits of institutional diversity in the banking sector appear during a period of financial crisis, when diversity shields the sector to some extent from contagion effects that would be exacerbated by a lack of diversity (Haldane \& May|2011).

Interestingly, intrabank diversification almost mirrors the results of the institutional diversity but with an opposite sign. A high share of non-interest income is insignificant for bank stability in the pre-crisis period but shows a strongly negative effect during the crisis. Another covariate that deserves particular attention is the Lerner index. As diversity is often associated with presence of competition in the banking sector, the positive correlation between the 
Lerner index and Z-Score3 seems to be counterintuitive at first sight. However, the Lerner Index measures banks' ability to set prices higher than that implied by perfect competition, while the diversity measures capture the distinctness of bank types or sizes in the country's banking system. In reality, the two banking system characteristics appear to be complementary in promoting bank stability.

In line with expectations, lower levels of leverage promote bank stability across the sample period. Asset growth has a similar general impact on stability but with the hypothesized negative sign. The country-level variables are all significant; consistent with the findings of Langfield \& Pagano (2016) a higher ratio of bank assets to GDP has a negative and highly significant impact on bank stability. In addition, increasing the share of credit in the economy, either with respect to GDP or with respect to market capitalization, reduces individual bank stability. This confirms the notion that a high ratio of private sector credit in relation to GDP or the market value of listed firms is not necessarily a good thing (Cecchetti \& Kharroubi 2012, Arcand et al. 2015). The coefficient of inflation is positive and significant, implying that easing fixed-rate borrowers' debt burden more than compensates for the increased investment risk that higher inflation might induce.

\subsubsection{Is the diversity-stability relationship homogeneous across bank type?}

Table 6 reports the average marginal effects for cooperative, savings and commercial banks in the pre-crisis and crisis period. Figure 5 illustrates the effects of both diversity indicators with 95\% confidence intervals. The effect of the indicator FinStruct on the stability of cooperative and saving banks is positive and significant. The post-2007 coefficient is higher in magnitude, but is statistically different from the pre-2007 coefficient only for savings banks (see Table 7). In contrast, for commercial banks the two coefficients are negative, significant and very similar in magnitude, implying that a higher degree of institutional diversity negatively affects commercial banks' stability. When we turn to the effect of FinDivers in Figure 5 , we see a different picture, as the effect of FinDivers is positive and significant for cooperative banks in the post-2007 period and, in contrast with findings for FinStruct, also for commercial banks, but it fails to be significant in the other case. The post-2007 coefficients are higher in magnitude 
and statistically distinguishable from the pre-2007 coefficient for savings banks (10\% level) and commercial banks (5\% level) (Table 7). To conclude, the results show that the impact of institutional diversity on bank stability partially varies over diversity indicators and bank types.

\subsubsection{How does the diversity-stability relationship change across bank size and growth?}

Key bank-level indicators may influence the diversity-stability relationship. In order to test this hypothesis we run the interaction model of Equation (2) with the interaction term FinStruct $^{*} Y_{i, c, t-1}$ and FinDivers ${ }^{*} Y_{i, c, t-1}$ instead of FinStruct and FinDivers, respectively, where $Y_{i, c, t-1}$ represents the standardized variables of Size, Asset Growth and the Lerner index. All other variables are the same as described in Subsection 4.1. Figure 6 reports how the impact of the variable FinStruct on Z-Score3 changes for increasing values of $Y_{i, c, t-1}$ in the two subamples. In the top panel we observe that there is a negative relationship between bank size and the positive impact of diversity on stability. The positive effect on stability tends to vanish for banks in the highest deciles of the size distribution and, interestingly, it is higher in the 2007-2014 subsample. For example, for banks in the bottom decile, the impact of diversity is $60 \%$ higher in the crisis period than in the prior period. From the middle and the bottom panel it appears that the diversity-stability relationship is constant across the distributions of asset growth and the Lerner index, although there is evidence of a decreasing intensity of the relationship of interest along the distribution of asset growth in the post-2007 sample.

Figure 7 shows the evolution of the FinDivers-stability relationship. It appears that size, growth and the Lerner index influence the relation of interest only in the crisis period. In particular, the top and middle panel show that larger size or higher asset growth have a dampening effect on the diversity-stability relationship, while, interestingly, the relationship of interest is increasing in the Lerner index.

\subsection{Does institutional diversity affect the ROA Risk?}

Institutional diversity is expected to have a risk-smoothing effect when a financial crisis hits the banking sector. Table 8 presents the estimation results of Equation (2) with the standard deviation of $R O A$ over a rolling window of 3 years as the dependent variable (ROA Risk). The findings reveal that in crisis times banks in more institutionally diverse banking systems 
generally face a lower ROA Risk than their peers located in less diverse banking sectors. By disentangling the results for bank types (Figure 8) we observe that FinDivers matters more for the ROA Risk than FinStruct, and the risk smoothing effects are only apparent in the crisis period. An increase in FinStruct significantly smooths the cooperative banks' ROA Risk while savings and commercial banks remain unaffected. In contrast, the effect of FinDivers on ROA Risk is weakly significant for all bank types in the post-2007 period. That is, when the crisis hits, greater diversity in terms of a less concentrated banking system balances the ROA Risk for all bank types.

\section{Robustness checks}

The first robustness test evaluates the sensitivity of results responding to the definition of crisis times. Instead of using the simple dichotomy pre- and post-2007, we construct a dummy variable AcuteCrisis using the detailed crisis data from Lo Duca et al. (2017), and interact it with bank type, diversity indicators and covariates. Table 9 reports AME for the complete sample, non-crisis and acute crisis periods. The results for the variables of interest FinStruct and FinDivers are very similar to those reported in Table 5 indicating that simply distinguishing between the pre-2007 and post-2007 period serves as a good approximation to identify the specific influence of the financial crisis on the diversity-stability nexus. The findings reveal that the AME in the acute crisis years (FS Acute Crisis and FD Acute Crisis) are higher than in the no-crisis years (FS No Crisis and FD No Crisis). Testing for significance reveals again that the AME in the no-crisis and acute crisis periods differ in terms of statistical significance, implying that the stability-enhancing effect of banking sector diversity is higher when a financial crisis hits the sector. Figure 9 shows the marginal effects disentangled for bank type. The effects of banking sector diversity indicators on bank types appear to be stronger in a crisis period than in normal times although the difference of the pre-2007 and post-2007 coefficient per bank type is significant only for FinDivers and cooperative and commercial banks but not for FinStruct.

In the second robustness test we examine whether the results are robust to a redefined dependent variable Z-Score5. We apply a 5-year rolling window instead of a 3-year window to calculate the standard deviation of $R O A$. Table 10 reveals that findings are qualitatively similar. 


\section{Conclusions}

In this study, we examine the effect of banking sector diversity on the stability of individual banks, before and during the global financial crisis. We exploit a large unbalanced panel of banks from 22 European countries over the 1998-2014 period and apply differences-indifferences models to evaluate the impact of FinStruct and FinDivers on individual banks' ZScore.

We construct two measures of banking sector diversity, the first capturing the distribution of bank specialization and the second focusing on the distribution of bank types. Disentangling the diversity-stability relationship across non crisis and crisis periods we find evidence consistent with Haldane \& May (2011)'s proposition: in particular during crisis times banks located in more diverse banking systems exhibit greater stability. By disentangling the diversitystability relationship across bank types for both periods, we obtain clear evidence that cooperative banks benefit in general from higher structural diversity. In contrast, the diversity-stability relationship for savings and commercial banks is sensitive to the nature of diversity. Diversity in terms of a more even distribution of bank lines of business increases savings banks' stability, while commercial banks gain in the financial crisis years from a more even bank size distribution. Finally, inspecting the diversity-stability relationship at different points of the distribution of bank size and asset growth reveals that structural diversity promotes the stability of smaller and slowly-growing banks more than that of very large and rapidly-growing banks.

The obtained empirical evidence has important implications for the debate over design of a sustainable financial architecture. It calls for caution when designing financial sector regulation in order to avoid unintended side effects that could endanger banking sector diversity. 


\section{References}

Acharya, V. V., Hasan, I. \& Saunders, A. (2006), 'Should banks be diversified? evidence from individual bank loan portfolios', The Journal of Business 79(3), 1355-1412.

URL: https://ideas.repec.org/a/ucp/jnlbus/v79y2006i3p1355-1412.html

Adrian, T. \& Brunnermeier, M. K. (2016), 'Covar', American Economic Review 106(7), 1705-41.

URL: http://www.aeaweb.org/articles?id=10.1257/aer.20120555

Aghion, P., Bolton, P. \& Dewatripont, M. (2000), 'Contagious bank failures in a free banking system', European Economic Review 44(4-6), 713-718.

Akins, B., Li, L., Ng, J. \& Rusticus, T. O. (2016), 'Bank competition and financial stability: Evidence from the financial crisis', Journal of Financial and Quantitative Analysis 51(01), 1-28.

Arcand, J. L., Berkes, E. \& Panizza, U. (2015), 'Too much finance?', Journal of Economic Growth 20(2), 105-148.

URL: https://doi.org/10.1007/s10887-015-9115-2

Ayadi, R., Llewellyn, D., Schmidt, R., Arbak, E. \& de Groen, W. (2009), 'Investigating diversity in the banking sector in Europe: The performance and role of savings banks'. Centre for European Policy Studies (CEPS), Brussels.

URL: http://rymayadi.com/investigating-diversity-in-the-banking-sector-in-europe-the-performanceand-role-of-savings-banks/

Ayadi, R., Llewellyn, D., Schmidt, R., Arbak, E. \& de Groen, W. (2010), 'Investigating diversity in the banking sector in Europe: key developments, performance and role of cooperative banks'. Centre for European Policy Studies (CEPS), Brussels.

URL: $\quad$ http://rymayadi.com/investigating-diversity-in-the-banking-sector-in-europe-keydevelopments-performance-and-role-of-cooperative-banks/

Baele, L., Jonghe, O. D. \& Vennet, R. V. (2007), ‘Does the stock market value bank diversification?', Journal of Banking and Finance 31(7), 1999 - 2023.

URL: $h t t p: / / w w w . s c i e n c e d i r e c t . c o m / s c i e n c e / a r t i c l e / p i i / S 0378426607000118$

Banerjee, R. N., Gambacorta, L. \& Sette, E. (2017), The real effects of relationship lending, BIS Working Papers 662, Bank for International Settlements.

URL: $h$ ttps://ideas.repec.org/p/bis/biswps/662.html

Baum, C. F., Caglayan, M. \& Ozkan, N. (2009), 'The second moments matter: The impact of macroeconomic uncertainty on the allocation of loanable funds', Economics Letters 102(2), 8789.

URL: $h t t p s: / / i d e a s . r e p e c . o r g / a / e e e / e c o l e t / v 102 y 2009 i 2 p 87-89 . h t m l$

Baum, C. F., Schäfer, D. \& Talavera, O. (2011), ‘The impact of the financial system's structure on firms' financial constraints', Journal of International Money and Finance 30(4), 678-691.

URL: $h t t p: / / w w w . s c i e n c e d i r e c t . c o m / s c i e n c e / a r t i c l e / p i i / S 0261560611000349$ 
Beck, T., Demirguc-Kunt, A. \& Levine, R. (2005), 'Bank concentration and fragility: Impact and mechanics'. NBER Working Paper No. w11500.

URL: https://ideas.repec.org/p/nbr/nberwo/11500.html

Beck, T., Demirgüç-Kunt, A. \& Levine, R. (2006), ‘Bank concentration, competition, and crises: First results', Journal of Banking \& Finance 30(5), 1581-1603.

Beck, T., Demirgüc-Kunt, A. \& Singer, D. (2013), 'Is small beautiful? Financial structure, size and access to finance', World Development 52(C), 19-33.

URL: https://ideas.repec.org/a/eee/wdevel/v52y2013icp19-33.html

Beck, T., Jonghe, O. D. \& Schepens, G. (2013), ‘Bank competition and stability: Cross-country heterogeneity', Journal of Financial Intermediation 22(2), 218 - 244.

URL: http://www.sciencedirect.com/science/article/pii/S1042957312000344

Beltratti, A. \& Stulz, R. M. (2012), 'The credit crisis around the globe: Why did some banks perform better?', Journal of Financial Economics 105(1), 1-17.

Berger, A. N., Klapper, L. F. \& Turk-Ariss, R. (2008), Bank competition and financial stability, Policy Research Working Paper Series 4696, The World Bank.

URL: $h t t p s: / / i d e a s . r e p e c . o r g / p / w b k / w b r w p s / 4696 . h t m l$

Boot, A. W. (2014), 'Banken echt niet gezond na deze stresstest', NRC Handelsblad (Opinie) (28 October).

Brock, W. A. (1983), 'Contestable markets and the theory of industry structure: A review article', Journal of Political Economy 91(6), 1055-1066.

URL: $h t t p: / / w w w . j s t o r . o r g / s t a b l e / 1831204$

Calomiris, C. W. \& Kahn, C. M. (1991), 'The role of demandable debt in structuring optimal banking arrangements', The American Economic Review pp. 497-513.

Cecchetti, S. \& Kharroubi, E. (2012), Reassessing the impact of finance on growth, BIS Working Papers 381, Bank for International Settlements.

URL: https://EconPapers.repec.org/RePEc:bis:biswps:381

Cihák, M. M. \& Schaeck, K. (2007), Banking competition and capital ratios, number 7-216, International Monetary Fund.

Claessens, S. \& Laeven, L. (2004), 'What drives bank competition? some international evidence', Journal of Money, Credit and Banking 36(3), 563-583.

URL: $h t t p: / / w w w . j s t o r . o r g / s t a b l e / 3838954$

De Nederlandsche Bank N.V. (2015), 'Perspective on the structure of the Dutch banking sector', DNB Study.

URL: https://www.dnb.nl/en/news/news-and-archive/dnbulletin-2015/dnb323320.jsp

Demirgüç-Kunt, A. \& Huizinga, H. (2010), 'Bank activity and funding strategies: The impact on risk and returns', Journal of Financial Economics 98(3), 626-650. 
Dimon, J. (2016), 'Large Banks and Small Banks Are Allies, Not Enemies', Wall Street Journal (April 5).

Drehmann, M. \& Tarashev, N. (2013), 'Measuring the systemic importance of interconnected banks', Journal of Financial Intermediation 22(4), 586-607.

Duprey, T. \& Lè, M. (2016), Bankscope Dataset: Getting Started, Technical report.

European Banking Authority (2016), EBA report on SMEs and SME supporting factor, Report $\mathrm{EBA} / \mathrm{OP} / 2016 / 04$.

Freixas, X., Parigi, B. M. \& Rochet, J.-C. (2000), 'Systemic risk, interbank relations, and liquidity provision by the central bank', Journal of Money, Credit and Banking pp. 611-638.

Gambacorta, L., Yang, J. \& Tsatsaronis, K. (2014), 'Financial structure and growth', BIS Quarterly Review .

URL: $h$ ttps://ideas.repec.org/a/bis/bisqtr/1403e.html

Gehrig, T. \& Iannino, M. C. (2017), Did the basel process of capital regulation enhance the resiliency of european banks?, CEPR Discussion Papers 11920, C.E.P.R. Discussion Papers.

URL: https://EconPapers.repec.org/RePEc:cpr:ceprdp:11920

Goetz, M. R. (2018), 'Competition and bank stability', Journal of Financial Intermediation 35, 57 69.

URL: $h t t p: / / w w w . s c i e n c e d i r e c t . c o m / s c i e n c e / a r t i c l e / p i i / S 1042957317300426$

Goodfriend, M. \& King, R. G. (1988), 'Financial deregulation, monetary policy, and central banking', FRB Richmond Economic Review 74(3), 3-22.

Gropp, R., Gruendl, C. \& Guettler, A. (2014), 'The impact of public guarantees on bank risktaking: Evidence from a natural experiment" ${ }^{* \prime}$ Review of Finance 18(2), 457-488.

URL: + http://dx.doi.org/10.1093/rof/rft014

Guerry, N. \& Wallmeier, M. (2017), 'Valuation of diversified banks: New evidence', Journal of Banking \& Finance 80, 203-214.

Haldane, A. (2009), 'Rethinking the financial network', BIS Review 53/2009.

URL: www.bis.org/review/r090505e.pdf

Haldane, A. G. \& May, R. M. (2011), 'Systemic risk in banking ecosystems.', Nature 469(7330), 351-5.

URL: http://www.nature.com/nature/journal/v469/n7330/full/nature09659.html

Hoerova, M., Mendicino, C., Nikolov, K., Schepens, G. \& Heuvel, S. V. d. (2018), Benefits and costs of liquidity regulation, Working Paper Series 2169, European Central Bank.

URL: https://ideas.repec.org/p/ecb/ecbwps/20182169.html

Huang, R. \& Ratnovski, L. (2011), 'The dark side of bank wholesale funding', Journal of Financial Intermediation 20(2), 248-263. 
Hubert, F. \& Schaefer, D. (2002), ‘Coordination Failure with Multiple-Source Lending, the Cost of Protection Against a Powerful Lender', Journal of Institutional and Theoretical Economics (JITE) 158(2), 256-256.

URL: https://ideas.repec.org/a/mhr/jinste/urnsici0932-4569(200206)1582_256cfwmlt_2.0.tx_2h.html

Jasova, M., Mendicino, C. \& Supera, D. (2018), Rollover Risk and Bank Lending Behavior: Evidence from Unconventional Central Bank Liquidity, Technical report.

Köhler, M. (2015), 'Which banks are more risky? the impact of business models on bank stability', Journal of Financial Stability 16, 195 - 212.

URL: $h t t p: / / w w w . s c i e n c e d i r e c t . c o m / s c i e n c e / a r t i c l e / p i i / S 157230891400028 X$

König, P. J. (2015), 'Liquidity Requirements: A Double-Edged Sword', International Journal of Central Banking 11(4), 129-168.

URL: https://ideas.repec.org/a/ijc/ijcjou/y2015q5a4.html

Laeven, L. \& Levine, R. (2007), 'Is there a diversification discount in financial conglomerates?', Journal of Financial Economics 85(2), 331 - 367. The economics of conflicts of interest financial institutions.

URL: http://www.sciencedirect.com/science/article/pii/S0304405X05002217

Langfield, S. \& Pagano, M. (2016), 'Bank bias in Europe: effects on systemic risk and growth', Economic Policy 31(85), 51-106.

URL: https://doi.org/10.1093/epolic/eiv019

Lerner, A. (1934), 'The concept of monopoly and the measurement of monopoly power', Review of Economic Studies 1, 157 - 175.

Leroy, A. \& Lucotte, Y. (2017), 'Is there a competition-stability trade-off in European banking?', Journal of International Financial Markets, Institutions and Money 46, 199 - 215.

URL: http://www.sciencedirect.com/science/article/pii/S1042443116300907

Levine, R. (2002), 'Bank-based or market-based financial systems: Which is better?', Journal of Financial Intermediation 11(4), 398-428.

URL: $h t t p: / / w w w . s c i e n c e d i r e c t . c o m / s c i e n c e / a r t i c l e / p i i / S 1042957302903414$

Li, X. \& Malone, C. (2016), 'Measuring bank risk: An exploration of z-score', SSRN Electronic Journal .

Lo Duca, M., Koban, A., Basten, M., Bengtsson, E., Klaus, B., Kusmierczyk, P., Lang, J. H., Detken, C. \& Peltonen, T. (2017), A new database for financial crises in European countries, Occasional Paper Series 194, European Central Bank.

URL: https://ideas.repec.org/p/ecb/ecbops/2017194.html

Manove, M., Padilla, A. J. \& Pagano, M. (2001), 'Collateral versus project screening: A model of lazy banks', Rand Journal of Economics 32(4), 726-744. 
Moudud-Ul-Huq, S. (2019), 'Banks' capital buffers, risk, and efficiency in emerging economies: are they counter-cyclical?', Eurasian Economic Review 9(4), 467-492.

Pino, G. \& Sharma, S. C. (2019), 'On the contagion effect in the US banking sector', Journal of Money, Credit and Banking 51(1), 261-280.

URL: https://onlinelibrary.wiley.com/doi/abs/10.1111/jmcb.12489

Schaeck, K. \& Cihàk, M. (2014), 'Competition, efficiency, and stability in banking', Financial Management 43(1), 215-241.

URL: $h t t p: / / d x$.doi.org/10.1111/fima.12010

Schaeck, K., Wolfe, S. \& Cihàk, M. (2009), 'Are competitive banking systems more stable?', Journal of Money, Credit and Banking 41(4), 711-734.

URL: $h t t p: / / d x$. doi.org/10.1111/j.1538-4616.2009.00228.x

Schäfer, D., Siliverstovs, B. \& Terberger, E. (2010), 'Banking competition, good or bad? The case of promoting micro and small enterprise finance in Kazakhstan', Applied Economics 42(6), 701716.

URL: $h t t p: / / d x$. doi.org/10.1080/00036840701720820

Schmid, M. M. \& Walter, I. (2009), 'Do financial conglomerates create or destroy economic value?', Journal of Financial Intermediation 18(2), 193 - 216.

URL: $h t t p: / / w w w . s c i e n c e d i r e c t . c o m / s c i e n c e / a r t i c l e / p i i / S 1042957308000326$

Segura, A. \& Suarez, J. (2017), 'How Excessive Is Banks' Maturity Transformation?', The Review of Financial Studies 30(10), 3538-3580.

URL: https://doi.org/10.1093/rfs/hhx054

Shannon, C. E. (1948), 'A mathematical theory of communication', The Bell System Technical Journal 27(July), 379-423.

Simpson, E. H. (1949), 'Measurement of diversity', Nature (163), 688.

Stiroh, K. J. \& Rumble, A. (2006), 'The dark side of diversification: The case of US financial holding companies', Journal of Banking \& Finance 30(8), 2131 - 2161.

URL: http://www.sciencedirect.com/science/article/pii/S0378426605001342

Ueda, K. \& di Mauro, B. W. (2013), 'Quantifying structural subsidy values for systemically important financial institutions', Journal of Banking and Finance 37(10), 3830 - 3842.

URL: $h t t p: / / w w w . s c i e n c e d i r e c t . c o m / s c i e n c e / a r t i c l e / p i i / S 0378426613002380$

Wagner, W. (2007), 'The liquidity of bank assets and banking stability', Journal of Banking $\mathcal{E}$ Finance 31(1), 121-139.

Williams, R. (2018), Marginal effects for continuous variables, mimeo, University of Notre Dame.

URL: https://www3.nd.edu/rwilliam/stats3/Margins02.pdf 
Table 1: Definition of variables

\begin{tabular}{|c|c|c|}
\hline Variable & Description & Source/BS variable name* \\
\hline ROA & Return on assets: pre-tax profits over assets for each bank & BS: Pre_tax_Profit, $t \_$asset \\
\hline ROA Risk $(\sigma($ ROA3) $)$ & Standard deviation of ROA for each bank, computed over the past 3 years & BS: calibrated ROA \\
\hline$\sigma(\mathrm{ROA} 5)$ & $\begin{array}{l}\text { Standard deviation of ROA for each bank, computed over the past } 5 \text { years for robustness } \\
\text { checks }\end{array}$ & BS: calibrated ROA \\
\hline Z-Score3 & Sum of ROA and equity over tot assets divided by $\sigma(\mathrm{ROA} 3)$ & BS: calibrated ROA, equity_over_asset \\
\hline Z-Score5 & Sum of ROA and equity over tot assets divided by $\sigma$ (ROA5) & BS: calibrated ROA, equity_over_asset \\
\hline FinStruct & $\begin{array}{l}\text { Diversity indicator representing the distribution of assets of the three bank groups Cooperative, } \\
\text { Savings and Commercial banks calculated using the Shannon Index }-\sum_{j=1}^{J} S_{j, c, t} \ln S_{j, c, t} \text { with } \\
S_{j c t} \text { denoting each banking group } j^{\prime} \text { s share in country } c \text { total bank assets in year } t\end{array}$ & BS: special, $t \_a s s e t$ \\
\hline FinDivers & $\begin{array}{l}\text { Diversity indicator calculated using the Gini-Simpson Index: } 1-\sum_{i=1}^{N}\left(S_{i, c, t}\right)^{2} \text { with } S_{i, c, t} \text { as } \\
\text { individual bank } i^{\prime} \text { s share in total assets of country } c \text { and year } t\end{array}$ & BS: $t \_a s s e t$ \\
\hline Post2007 & Dummy of value 1 if year $\geq 2007$ and 0 otherwise & \\
\hline Internal Divers & $\begin{array}{l}\text { Indicator for bank-internal diversification calculated as non-interest operating income over } \\
\text { total operating income }\end{array}$ & $\begin{array}{l}\text { BS: Total_Non_Int_Operating_Inc, Operat- } \\
\text { ing_Income_Memo }\end{array}$ \\
\hline MC & $\begin{array}{l}\text { Marginal cost for each bank obtained by modelling the total operating cost of running a bank } \\
\text { as a function of a single aggregate output proxy, } Q_{i, t} \text { and three input prices }\end{array}$ & $\begin{array}{l}\text { BS: Personnel_Expenses, Total_Int_Expense, } \\
\text { Other_Operating_Expenses, Total_Deposits_Mo- } \\
\text { ney_Market_and, t_asset }\end{array}$ \\
\hline $\mathrm{P}$ & Product price (proxied by total revenues) for each bank & $\begin{array}{l}\text { BS: Gross_Int_and_Dividend_Inco, other_op_in- } \\
\text { come, t_asset }\end{array}$ \\
\hline Lerner Index & $\frac{P_{i, c, t}-M C_{i, c, t}}{P_{i, c, t}}$, difference of price $P$ and marginal cost $M C$ scaled by price $P$ & $\begin{array}{l}\text { BS: Gross_Int_and_Dividend_Inco, other_op_in- } \\
\text { come, t_asset }\end{array}$ \\
\hline Efficiency & Cost to income ratio & BS: cost_income_ratio \\
\hline Wholesale Funding & Total funding mines deposit funding over total funding & BS: Total_Funding, deposit_ST_funding \\
\hline Liquidity & Liquid assets over total assets & BS: liquid_asset, $\mathrm{t}$ _asset \\
\hline Equity over Liabilities & Indebtedness indicator: equity over liabilities & BS: equity_over_liab \\
\hline Net Income over Assets & Net earning capacity per unit of assets calibrated as net income over total assets & BS: Net_Income, $t$ _asset \\
\hline Size & Natural logarithm of a bank's total assets & BS: $t \_a s s e t$ \\
\hline Asset Growth & Growth rate of a bank's total assets & BS: t_asset \\
\hline Equity over assets & Total equity divided by total assets & BS: equity_over_asset \\
\hline Sector Size & Deposit money banks' assets to GDP & GFDD \\
\hline Financial Depth & Ratio of private credit by deposit money banks to GDP of home country & GFDD \\
\hline Credit to MarketCap & Ratio of private credit by deposit money banks to stock market capitalization & GFDD \\
\hline Inflation & Inflation in banks' home country & ES \\
\hline AcuteCrisis & Dummy of value 1 indicating a systemic crisis and 0 otherwise & Lo Duca et al. 2017) \\
\hline
\end{tabular}

Note: * BS= Bankscope, GFDD = World Bank's Global Financial Development Database and ES= Eurostat. BS variables are named following Duprey \& Lè 2016) 
Table 2: Country labels, number of observations and banking sector size by country

\begin{tabular}{|c|c|c|c|c|}
\hline Country & Frequency & Percent & $\begin{array}{l}\text { Aggregated } \\
\text { total assets }\end{array}$ & Percent \\
\hline Austria & 2097 & 5.41 & 370.14 & 2.2 \\
\hline Belgium & 230 & 0.59 & 361.32 & 2.1 \\
\hline Bulgaria & 123 & 0.32 & 23.43 & 0.1 \\
\hline Croatia & 303 & 0.78 & 31.67 & 0.2 \\
\hline Cyprus & 147 & 0.38 & 40.97 & 0.2 \\
\hline Denmark & 932 & 2.41 & 437.65 & 2.6 \\
\hline Finland & 88 & 0.23 & 154.54 & 0.9 \\
\hline France & 2103 & 5.43 & 2436.50 & 14.5 \\
\hline Germany & 21862 & 56.45 & 3605.28 & 21.4 \\
\hline Greece & 131 & 0.34 & 239.62 & 1.4 \\
\hline Ireland & 69 & 0.18 & 240.48 & 1.4 \\
\hline Italy & 7071 & 18.26 & 1859.01 & 11.0 \\
\hline Latvia & 100 & 0.26 & 12.72 & 0.1 \\
\hline Lithuania & 78 & 0.20 & 11.98 & 0.1 \\
\hline Netherlands & 220 & 0.57 & 918.49 & 5.5 \\
\hline Portugal & 360 & 0.93 & 280.21 & 1.7 \\
\hline Romania & 163 & 0.42 & 39.24 & 0.2 \\
\hline Slovak Republic & 139 & 0.36 & 37.82 & 0.2 \\
\hline Slovenia & 176 & 0.45 & 27.78 & 0.2 \\
\hline Spain & 1283 & 3.31 & 1797.76 & 10.7 \\
\hline Sweden & 614 & 1.59 & 418.54 & 2.5 \\
\hline United Kingdom & 440 & 1.14 & 3494.87 & 20.8 \\
\hline Total & 38729 & 100.00 & 16839.99 & 100 \\
\hline
\end{tabular}


Table 3: Expected sign of variables

\begin{tabular}{lcr}
\hline Variable & Expected sign & Level \\
\hline FinStruct & $(+)$ & Country \\
FinDivers & $(+)$ & Country \\
IntDivers & $(+,-)$ & Bank \\
Lerner Index & $(+)$ & Bank \\
Efficiency & $(-)$ & Bank \\
Wholesale Funding & $(-,+)$ & Bank \\
Liquidity & $(+)$ & Bank \\
Equity over Liabilities & $(+)$ & Bank \\
Net Income over Assets & $(+)$ & Bank \\
Size & $(-,+)$ & Bank \\
Asset Growth & $(-)$ & Bank \\
Sector Size & $(-)$ & Country \\
Financial Depth & $(-,+)$ & Country \\
Credit to MarkCap & $(-,+)$ & Country \\
Inflation & $(-,+)$ & Country \\
\hline
\end{tabular}

Note: The Table shows the expected relationship between the dependent variable (Z-Score) and all covariates included in the analysis, listed in the first column. We use bank-level and country-level controls. The variables of interest, FinStruct and FinDivers are at the country-level. The symbols (+)/(-) indicate whether the relationship is expected to be positive/negative. 
Table 4: Summary Statistics

\begin{tabular}{llccr}
\hline Variable & Mean & SD & Min & Max \\
\hline ROA & 0.0066 & 0.0059 & -0.02 & 0.033 \\
ROA Risk & 0.0028 & 0.0033 & 0.000027 & 0.047 \\
Z-Score3 & 103 & 172 & 1.3 & 1363 \\
Z-Score5 & 47 & 51 & 1.4 & 426 \\
Internal Divers & 0.28 & 0.12 & -0.047 & 1 \\
Lerner Index & 0.2 & 0.099 & -0.51 & 0.48 \\
Efficiency & 0.68 & 0.14 & 0.055 & 9.9 \\
Wholesale Funding & 0.085 & 0.12 & -.0029 & 1 \\
Liquidity & 0.17 & 0.13 & 0.013 & 0.85 \\
Equity over Liabilities & 0.089 & 0.048 & 0.029 & 0.44 \\
Net Income over Assets & 0.0041 & 0.0048 & -0.032 & 0.035 \\
Asset Growth & 0.062 & 0.14 & -0.35 & 0.73 \\
Size & 6.8 & 1.5 & 3 & 12 \\
\hline Sector size & 118 & 27 & 11 & 261 \\
FinStruct & 0.413 & 0.319 & 0 & 1.034 \\
FinDivers & 0.819 & 0.087 & 0.0375 & 0.954 \\
Financial Depth & 88.546 & 48.954 & 6.383 & 260.704 \\
Credit to MarkCap & 319.270 & 431.532 & 21.510 & 3449.991 \\
Inflation & 3.145 & 3.9 & -1.355 & 45.667 \\
\hline Observations & 38729 & & & \\
\hline
\end{tabular}

Note: This Table shows the total sample summary statistics for the covariates used throughout the paper. Bank-level data is retrieved from the Bankscope database; the country-level data is collected from the GFDD. The full sample contains 38729 observations. The table consists of two parts. The first panel contains information on the mean, standard deviation, min and max of the bank level variables; the bottom panel includes information on the country-level variables 
Figure 1: The Distribution of Domestic Banking Sectors' Institutional Diversity
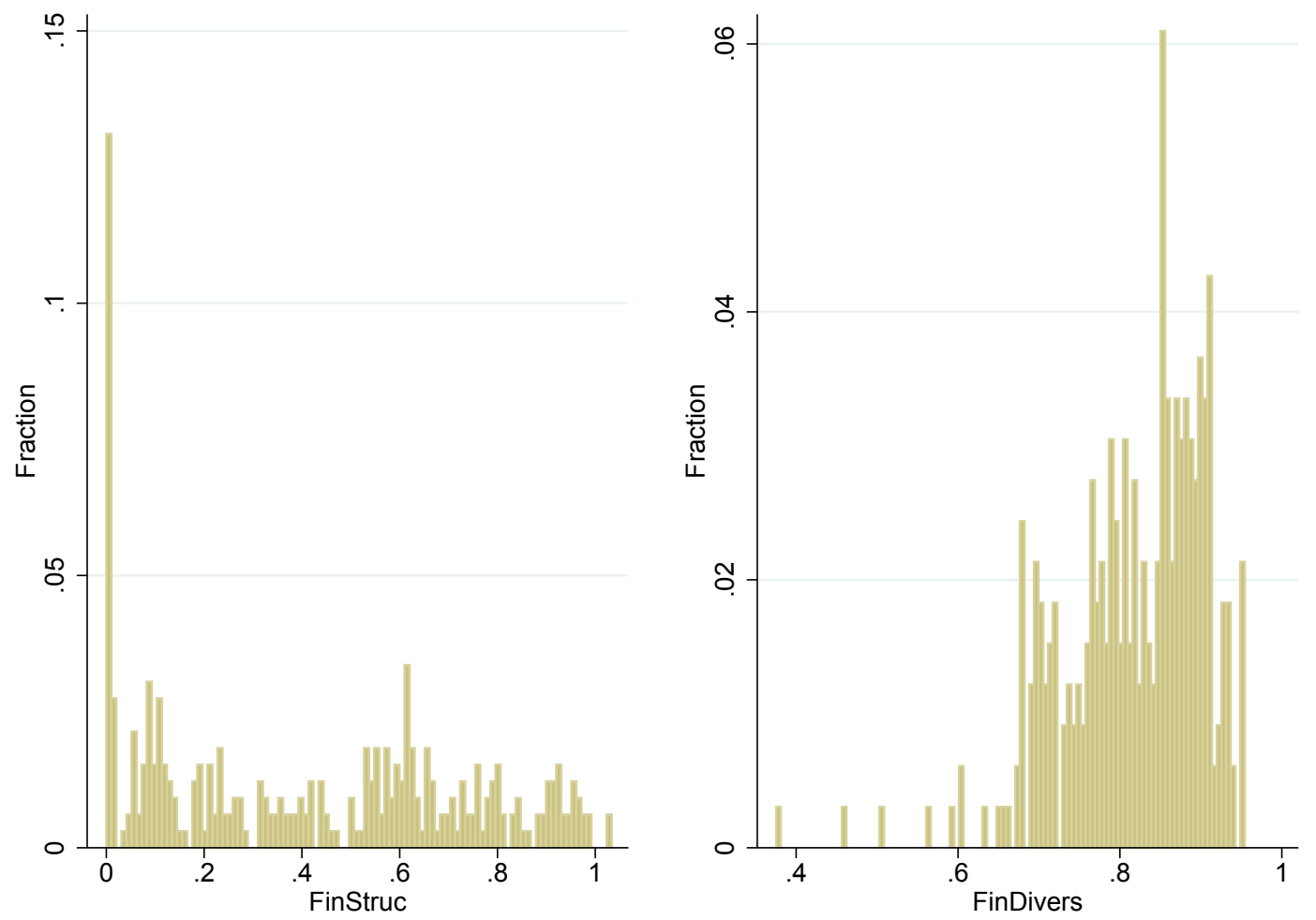

Note: The Figure shows the distribution between 1998 and 2014 of our variables of interest: the two measures of banking sector diversity. The first measure, FinStruct, is calculated as the Shannon Index and it quantifies the uncertainty in predicting the group identity of a bank that is taken at random from the dataset. FinDivers is calculated as 1-HHI, where HHI is the Herfindahl Index. For a detailed explanation of the construction of the two measures, please refer to Section 3.2 . 
Figure 2: Domestic Institutional Diversity and Bank Stability - Evolution over Time

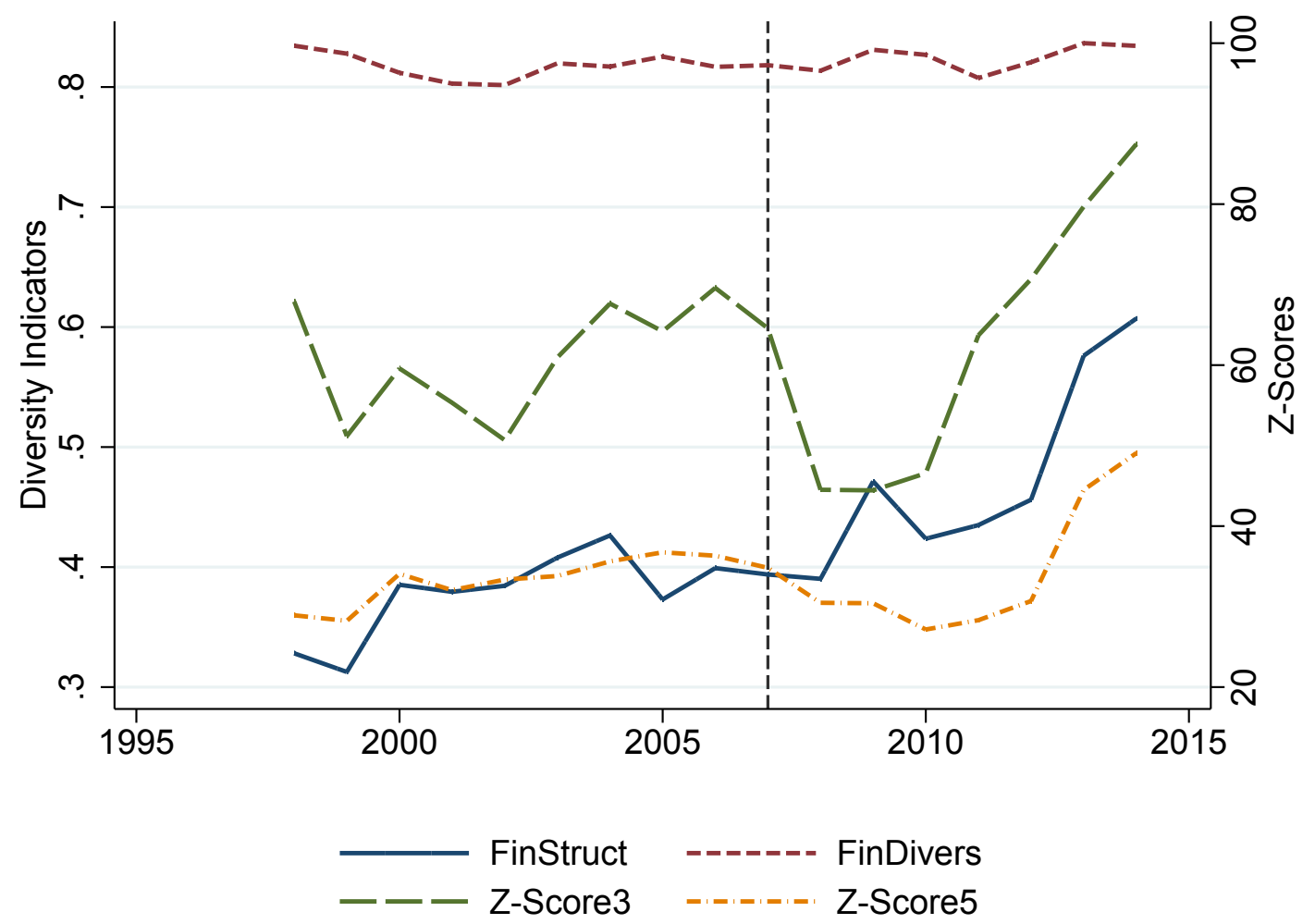

Note: The Figure shows the evolution over time of banking sector diversity and bank stability. The first measure of banking sector stability is FinStruct, that is calculated as the Shannon Index. It quantifies the uncertainty in predicting the group identity of a bank that is taken at random from the dataset. The second measure of diversity is FinDivers, calculated as $1-H H I$, where HHI is the Herfindahl Index. Bank stability is captured by the Z-Score. In general, the Z-Score equals the sum of equity over total assets and return on assets divided by the standard deviation of return on assets. Z-Score 3 is calibrated using the three year rolling standard deviation of return on assets. Z-Score 5 is calculated using the five year rolling standard deviation of return on assets. Both Z-Scores indicators are initially calculated at the bank-year level and then averaged by country on a yearly basis. For a detailed explanation of the construction of the two diversity measure, please refer to Section 3.2 For a detailed explanation of the construction of the two Z-Score measures, please refer to Section 3.3 
Figure 3: Evolution of Institutional Diversity in the Domestic Banking Sector by Country
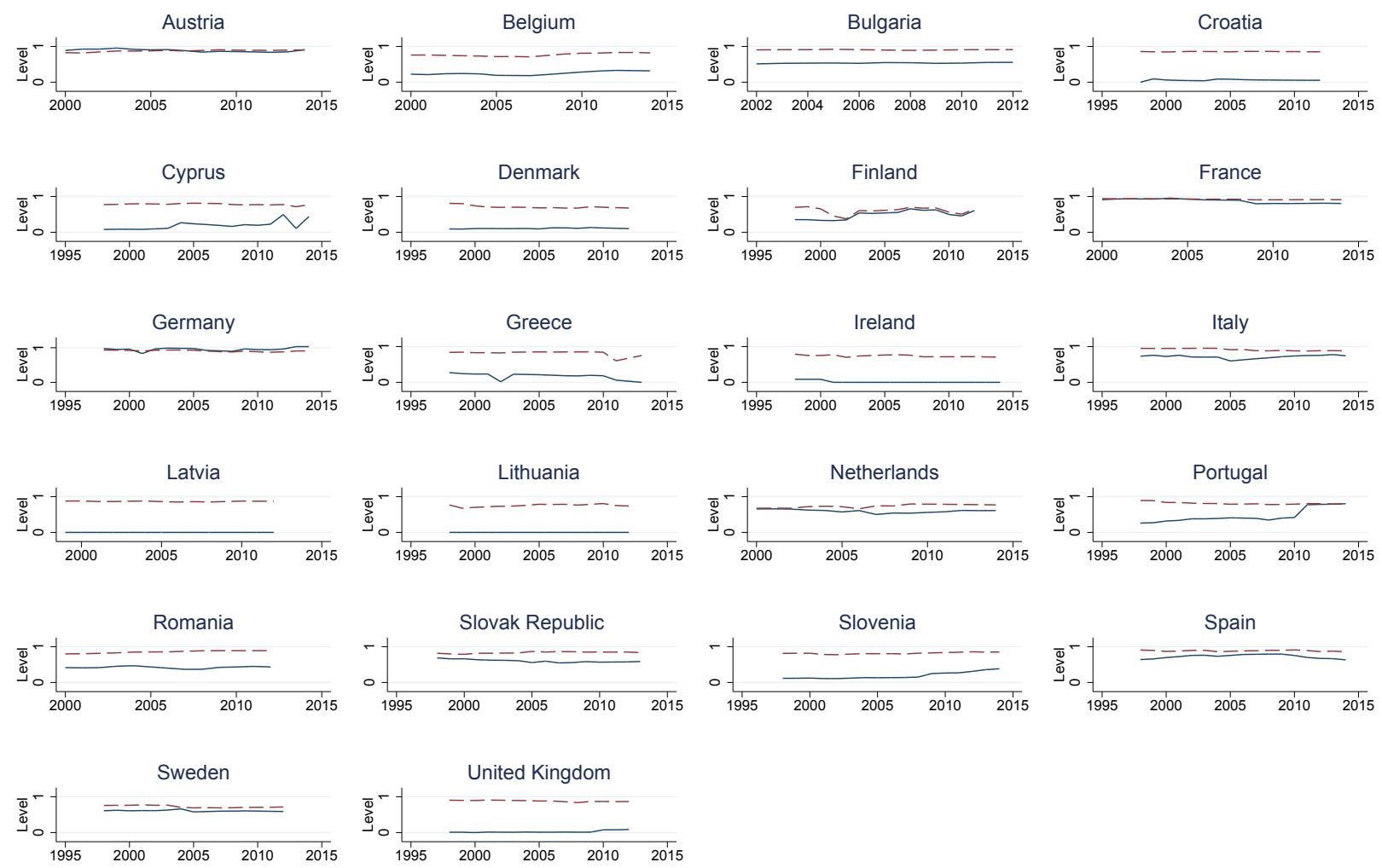

FinStruct

\section{FinDivers}

Note: The Figure shows the evolution over time of the two measures of banking sector diversity in the countries included in the analysis. The first measure, FinStruct, is calculated as the Shannon Index and it quantifies the uncertainty in predicting the group identity of a bank that is taken at random from the dataset. FinDivers is calculated as 1-HHI, where HHI is the Herfindahl Index. For a detailed explanation of the construction of the two measures please refer to Section 3.2 
Figure 4: Evolution of Bank Stability by Country
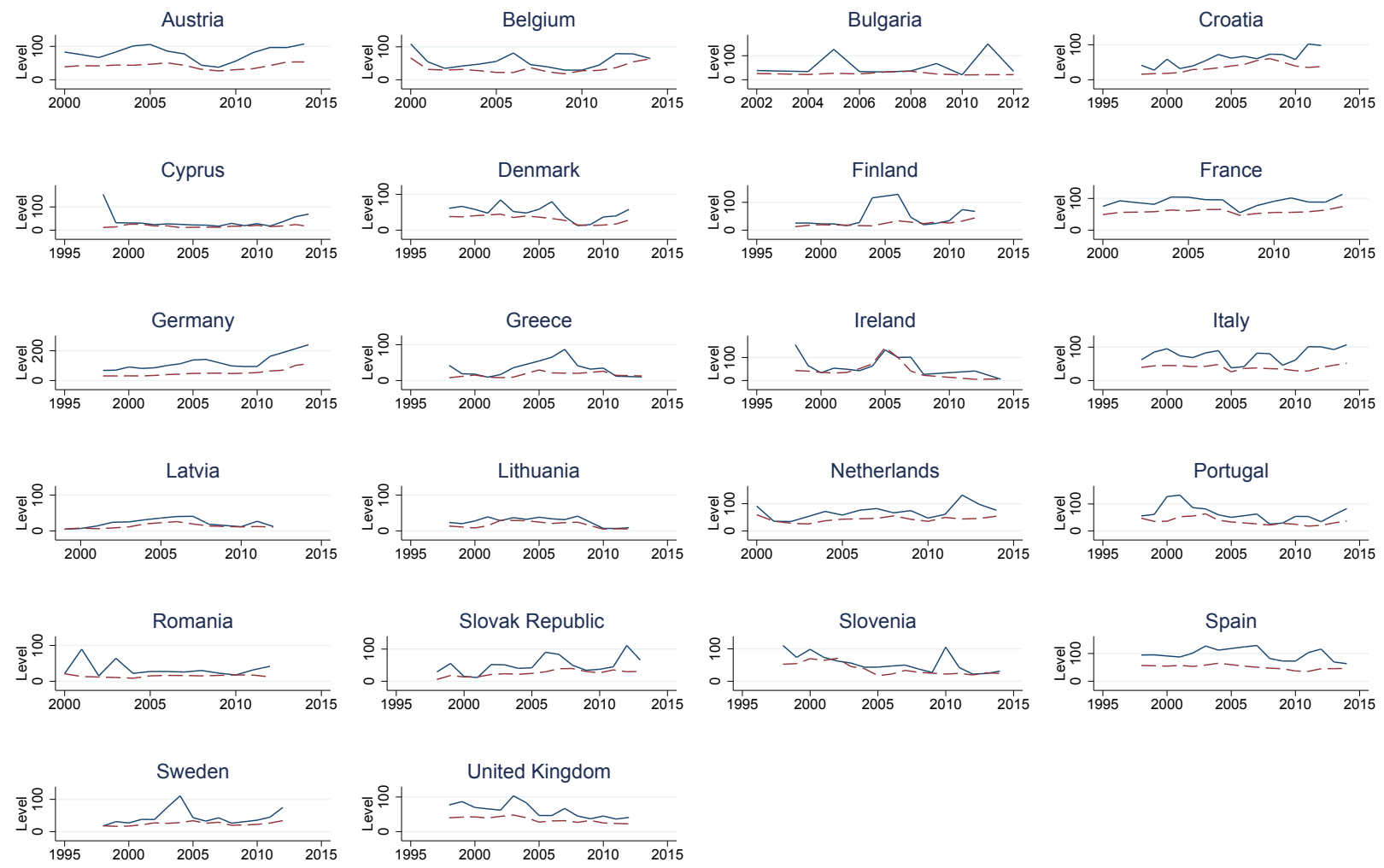

\section{Z-Score3}

\section{Z-Score5}

Note: The Figure shows the evolution over time in all countries included in the analysis of the two measures of bank stability used in the paper, Z-Score3 and Z-Score5. Z-Score3 equals the sum of equity over total assets and return on assets divided by the three year rolling standard deviation of return on assets. Z-Score5 is given by the sum of equity over total assets and return on assets divided by the five year rolling standard deviation of return on assets. Both indicators are initially calculated at the bank-year level and then averaged by country on a yearly basis. For a detailed explanation of the construction of the two Z-Score measures, please refer to Section 3.3 
Table 5: Banking Sector Diversity Effects on Bank Stability, Baseline Results

\begin{tabular}{|c|c|c|c|c|c|c|}
\hline & $\begin{array}{c}(1) \\
\text { Z-Score3 } \\
\text { Full Sample }\end{array}$ & $\begin{array}{c}(2) \\
\text { Z-Score3 } \\
1998-2006\end{array}$ & $\begin{array}{c}\text { (3) } \\
\text { Z-Score3 } \\
2007-2014\end{array}$ & $\begin{array}{c}\text { (4) } \\
\text { Z-Score3 } \\
\text { Full Sample }\end{array}$ & $\begin{array}{c}(5) \\
\text { Z-Score3 } \\
1998-2006\end{array}$ & $\begin{array}{c}(6) \\
\text { Z-Score3 } \\
2007-2014\end{array}$ \\
\hline FinStruct & $\begin{array}{c}0.195^{* * *} \\
(4.01)\end{array}$ & $\begin{array}{c}0.141^{* *} \\
(2.56)\end{array}$ & $\begin{array}{c}0.247^{* * *} \\
(4.99)\end{array}$ & & & \\
\hline FinDivers & & & & $\begin{array}{c}0.0480 \\
(1.53)\end{array}$ & $\begin{array}{l}0.0170 \\
(0.55)\end{array}$ & $\begin{array}{c}0.0781^{*} \\
(1.85)\end{array}$ \\
\hline Internal Divers & $\begin{array}{c}-0.180^{*} \\
(-1.91)\end{array}$ & $\begin{array}{c}-0.0754 \\
(-0.75)\end{array}$ & $\begin{array}{c}-0.281^{* *} \\
(-2.17)\end{array}$ & $\begin{array}{l}-0.188^{*} \\
(-1.96)\end{array}$ & $\begin{array}{c}-0.0699 \\
(-0.69)\end{array}$ & $\begin{array}{c}-0.302^{* *} \\
(-2.26)\end{array}$ \\
\hline Lerner Index & $\begin{array}{c}0.0291^{*} \\
(1.94)\end{array}$ & $\begin{array}{l}0.0158 \\
(1.05)\end{array}$ & $\begin{array}{c}0.0420^{* *} \\
(2.07)\end{array}$ & $\begin{array}{c}0.0286^{*} \\
(1.88)\end{array}$ & $\begin{array}{l}0.0113 \\
(0.75)\end{array}$ & $\begin{array}{c}0.0454^{* *} \\
(2.19)\end{array}$ \\
\hline Efficiency & $\begin{array}{c}-0.0269 \\
(-0.24)\end{array}$ & $\begin{array}{l}-0.152 \\
(-1.18)\end{array}$ & $\begin{array}{l}0.0942 \\
(0.74)\end{array}$ & $\begin{array}{l}-0.0456 \\
(-0.40)\end{array}$ & $\begin{array}{l}-0.212^{*} \\
(-1.67)\end{array}$ & $\begin{array}{l}0.115 \\
(0.89)\end{array}$ \\
\hline Wholesale Funding & $\begin{array}{l}-0.105 \\
(-1.28)\end{array}$ & $\begin{array}{l}-0.123 \\
(-0.90)\end{array}$ & $\begin{array}{c}-0.0870 \\
(-0.81)\end{array}$ & $\begin{array}{l}-0.155^{*} \\
(-1.67)\end{array}$ & $\begin{array}{l}-0.168 \\
(-1.16)\end{array}$ & $\begin{array}{l}-0.142 \\
(-1.16)\end{array}$ \\
\hline Liquidity & $\begin{array}{l}0.0822 \\
(0.81)\end{array}$ & $\begin{array}{l}0.197^{*} \\
(1.88)\end{array}$ & $\begin{array}{l}-0.0287 \\
(-0.22)\end{array}$ & $\begin{array}{c}0.0588 \\
(0.61)\end{array}$ & $\begin{array}{c}0.219^{* *} \\
(2.27)\end{array}$ & $\begin{array}{l}-0.0964 \\
(-0.75)\end{array}$ \\
\hline Equity over Liabilities & $\begin{array}{c}0.139^{* * *} \\
(4.83)\end{array}$ & $\begin{array}{c}0.105^{* * *} \\
(3.39)\end{array}$ & $\begin{array}{c}0.171^{* * *} \\
(5.28)\end{array}$ & $\begin{array}{c}0.161^{* * *} \\
(5.56)\end{array}$ & $\begin{array}{c}0.131^{* * *} \\
(4.24)\end{array}$ & $\begin{array}{c}0.190^{* * *} \\
(5.87)\end{array}$ \\
\hline Net Income over Assets & $\begin{array}{c}-0.00337 \\
(-0.23)\end{array}$ & $\begin{array}{c}-0.0119 \\
(-0.53)\end{array}$ & $\begin{array}{c}0.00494 \\
(0.27)\end{array}$ & $\begin{array}{c}-0.00505 \\
(-0.35)\end{array}$ & $\begin{array}{c}-0.0140 \\
(-0.62)\end{array}$ & $\begin{array}{c}0.00361 \\
(0.20)\end{array}$ \\
\hline Size & $\begin{array}{l}0.0281 \\
(1.24)\end{array}$ & $\begin{array}{l}0.0208 \\
(0.94)\end{array}$ & $\begin{array}{c}0.0352 \\
(1.33)\end{array}$ & $\begin{array}{l}0.0301 \\
(1.34)\end{array}$ & $\begin{array}{l}0.0256 \\
(1.15)\end{array}$ & $\begin{array}{c}0.0345 \\
(1.30)\end{array}$ \\
\hline Asset Growth & $\begin{array}{c}-0.629^{* * *} \\
(-12.26)\end{array}$ & $\begin{array}{c}-0.654^{* * *} \\
(-10.99)\end{array}$ & $\begin{array}{c}-0.605^{* * *} \\
(-7.46)\end{array}$ & $\begin{array}{c}-0.605^{* * *} \\
(-11.17)\end{array}$ & $\begin{array}{c}-0.634^{* * *} \\
(-10.47)\end{array}$ & $\begin{array}{c}-0.577^{* * *} \\
(-6.66)\end{array}$ \\
\hline Sector Size & $\begin{array}{c}-0.0147^{* * *} \\
(-4.20)\end{array}$ & $\begin{array}{c}-0.0156^{* * *} \\
(-2.94)\end{array}$ & $\begin{array}{c}-0.0138^{* * *} \\
(-4.35)\end{array}$ & $\begin{array}{c}-0.0153^{* * *} \\
(-3.93)\end{array}$ & $\begin{array}{c}-0.0171^{* * *} \\
(-3.32)\end{array}$ & $\begin{array}{c}-0.0135^{* * *} \\
(-3.12)\end{array}$ \\
\hline Financial Depth & $\begin{array}{l}0.0140^{* * *} \\
(3.28)\end{array}$ & $\begin{array}{c}0.0148^{* *} \\
(2.36)\end{array}$ & $\begin{array}{c}0.0131^{* * *} \\
(3.56)\end{array}$ & $\begin{array}{c}0.0131^{* * *} \\
(2.75)\end{array}$ & $\begin{array}{c}0.0150^{* *} \\
(2.43)\end{array}$ & $\begin{array}{c}0.0113^{* *} \\
(2.24)\end{array}$ \\
\hline Credit to MarkCap & $\begin{array}{c}-0.0315^{* * *} \\
(-2.60)\end{array}$ & $\begin{array}{c}-0.00918 \\
(-0.81)\end{array}$ & $\begin{array}{c}-0.0531^{* * *} \\
(-2.84)\end{array}$ & $\begin{array}{c}-0.0187^{*} \\
(-1.80)\end{array}$ & $\begin{array}{c}0.00450 \\
(0.49)\end{array}$ & $\begin{array}{c}-0.0411^{* *} \\
(-2.36)\end{array}$ \\
\hline Inflation & $\begin{array}{c}0.0325^{* *} \\
(2.41)\end{array}$ & $\begin{array}{l}0.0156 \\
(0.71)\end{array}$ & $\begin{array}{c}0.0489^{* * *} \\
(3.37)\end{array}$ & $\begin{array}{c}0.0282^{* *} \\
(2.05)\end{array}$ & $\begin{array}{c}0.00580 \\
(0.28)\end{array}$ & $\begin{array}{c}0.0499^{* * *} \\
(2.99)\end{array}$ \\
\hline Bank FE & yes & yes & yes & yes & yes & yes \\
\hline Year FE & yes & yes & yes & yes & yes & yes \\
\hline Observations & 38729 & 19059 & 19670 & 38729 & 19059 & 19670 \\
\hline
\end{tabular}

Note: The Table shows the Avarage Marginal Effect (AME) for FinStruct and FinDivers, and the other covariates. Columns 1 and 4 report results for the full sample; Columns 2 and 5 show results for the pre-2007 subsample (from 1998 to 2006); finally, Columns 3 and 6 contain results for the post-2007 subsample (from 2007 to 2014). Standard errors (in parenthesis) are clustered at the country-year level. The coefficients for FinStruct and FinDivers (1998-2006) are statistically different from FinStruct and FinDivers (2007-2014), respectively. Significance levels: ${ }^{*} p<0.1,{ }^{* *}$ $p<0.05,{ }^{* * *} p<0.01$. The AMEs for the variables are obtained by evaluating for each observation an $\varepsilon$-change in FinStruct, FinDivers and the other covariates, computing the derivative of Z-Score3 with respect to the covariates and then averaging over the total of observations. For example, for FinStruct we compute the predicted value using the observed values (cases) of the variable to generate FinStruct-Predict1. Then, we change the variable by a very small amount FinStruct $+\Delta$, where $\Delta$ is the standard deviation of the variable divided by 1000. In the next step, we compute the new predicted values for each case of FinStruct $+\Delta$ to generate FinStruct-Predict2. Finally, we compute $x m e=\frac{\text { FinStruct-Predict2-FinStruct-Predict1 }}{\Delta}$ and calculate the mean value of $x m e$. This procedure is equivalent to directly computing $\frac{\partial Z \text {-Score3 }}{\partial \text { FinStruct }}$ and, thus, the mean value of $x m e$ is the AME for FinStruct (Williams 2018). 
Table 6: Institutional Diversity Effects on Bank Stability by Bank Type, Pre- and Post-2007

\begin{tabular}{|c|c|c|c|c|c|c|}
\hline & $\begin{array}{c}(1) \\
\text { Z-Score3 } \\
\text { Coop Banks }\end{array}$ & $\begin{array}{c}(2) \\
\text { Z-Score3 } \\
\text { Sav Banks }\end{array}$ & $\begin{array}{c}\text { 1998-2006 } \\
(3) \\
\text { Z-Score3 } \\
\text { Comm Banks }\end{array}$ & $\begin{array}{c}(4) \\
\text { Z-Score3 } \\
\text { Coop Banks }\end{array}$ & $\begin{array}{c}(5) \\
\text { Z-Score3 } \\
\text { Sav Banks }\end{array}$ & $\begin{array}{c}(6) \\
\text { Z-Score3 } \\
\text { Comm Banks }\end{array}$ \\
\hline FinStruct & $\begin{array}{c}0.214^{* * *} \\
(2.59)\end{array}$ & $\begin{array}{c}0.156^{* *} \\
(2.56)\end{array}$ & $\begin{array}{c}-0.0716^{* *} \\
(-2.08)\end{array}$ & & & \\
\hline FinDivers & & & & $\begin{array}{c}0.0666 \\
(1.35)\end{array}$ & $\begin{array}{c}-0.0583 \\
(-1.46)\end{array}$ & $\begin{array}{c}0.0123 \\
(0.75)\end{array}$ \\
\hline Covariates & yes & yes & yes & yes & yes & yes \\
\hline Bank FE & yes & yes & yes & yes & yes & yes \\
\hline Year FE & yes & yes & yes & yes & yes & yes \\
\hline Observations & 9422 & 5985 & 3652 & 9422 & 5985 & 3652 \\
\hline & $\begin{array}{c}(7) \\
\text { Z-Score3 } \\
\text { Coop Banks }\end{array}$ & $\begin{array}{c}(8) \\
\text { Z-Score3 } \\
\text { Sav Banks }\end{array}$ & $\begin{array}{c}\text { 2007-2014 } \\
(9) \\
\text { Z-Score3 } \\
\text { Comm Banks }\end{array}$ & $\begin{array}{c}(10) \\
\text { Z-Score3 } \\
\text { Coop Banks }\end{array}$ & $\begin{array}{c}(11) \\
\text { Z-Score3 } \\
\text { Sav Banks }\end{array}$ & $\begin{array}{c}(12) \\
\text { Z-Score3 } \\
\text { Comm Banks }\end{array}$ \\
\hline FinStruct & $\begin{array}{c}0.328^{* * *} \\
(4.78)\end{array}$ & $\begin{array}{c}0.257^{* * *} \\
(3.43)\end{array}$ & $\begin{array}{c}-0.0632^{*} \\
(-1.69)\end{array}$ & & & \\
\hline FinDivers & & & & $\begin{array}{l}0.119^{*} \\
(1.80)\end{array}$ & $\begin{array}{c}0.0127 \\
(0.29)\end{array}$ & $\begin{array}{c}0.0410^{* *} \\
(2.13)\end{array}$ \\
\hline Covariates & yes & yes & yes & yes & yes & yes \\
\hline Bank FE & yes & yes & yes & yes & yes & yes \\
\hline Year FE & yes & yes & yes & yes & yes & yes \\
\hline Observations & 11267 & 5284 & 3119 & 11267 & 5284 & 3119 \\
\hline
\end{tabular}

Note: The Table reports the average marginal effects (AME) of FinStruct and FinDivers with respect to Z-Score3. The AMEs of other covariates are omitted. The coefficients are separately reported for different bank types (cooperative, saving and commercial banks). The panel above shows results for the period from 1998 to 2006, the panel below contains results for the period from 2007 to 2014. The AMEs for the variables are obtained by evaluating for each observation an $\epsilon$ change in FinStruct, FinDivers, computing the derivative of Z-Score3 with respect to the variables of interest and then averaging over the total of observations. The coefficient of FinStruct (1998-2006) is statistically different from the one for 2007-2014 for cooperative and savings but not for commercial banks. The coefficient of FinDivers (1998-2006) is statistically different from the one for 2007-2014 for commercial and savings banks but not for cooperative banks (see Table 7). Standard errors (in parenthesis) are clustered at the country-year level. Significance levels: ${ }^{*} p<0.1,{ }^{* *} p<0.05,{ }^{* * *} p<0.01$. 
Table 7: Pairwise Comparison of the Coefficients of Institutional Diversity by Bank Type, Pre and Post-2007

$H_{0}=$ equality of coeff $\quad \beta_{\mathrm{COOP}}^{\text {pre-2007 }}=\beta_{\mathrm{COOP}}^{\text {post-2007 }} \quad \beta_{\mathrm{SAV}}^{\text {pre-2007 }}=\beta_{\mathrm{SAV}}^{\text {post-2007 }} \quad \beta_{\mathrm{COMM}}^{\text {pre-2007 }}=\beta_{\mathrm{COMM}}^{\text {post-2007 }}$

FinStruct

\begin{tabular}{lccc} 
F-Statistic & 2.71 & 4.67 & 0.25 \\
$\mathrm{p}$ value & $(0.1009)$ & $(0.0315)$ & $(0.6207)$ \\
\hline
\end{tabular}

FinDivers

\begin{tabular}{lccc} 
F-Statistic & 0.61 & 3.45 & 4.09 \\
$\mathrm{p}$ value & $(0.4354)$ & $(0.0642)$ & $(0.0440)$ \\
\hline
\end{tabular}

Note: The Table shows the result for the F-test on the null hypothesis that two coefficients for the pre- and the crisis period are equal. We compare the effect of banking sector diversity pre and post 2007 for the three bank types under analysis. In the top panel we compare the pairwise coefficients contained in columns (1) and (7), (2) and (8), and (3)and (9) of Table 6, i.e. when institutional diversity is measured with FinStruct. In the bottom panel we compare the pairwise coefficients contained in columns (4) and (10), (5) and (11), and (6) and (12) of Table 6 , i.e. when institutional diversity is measured with FinDivers. 
Figure 5: Institutional Diversity Effects on Bank Stability by Bank Type - Pre and Post-2007
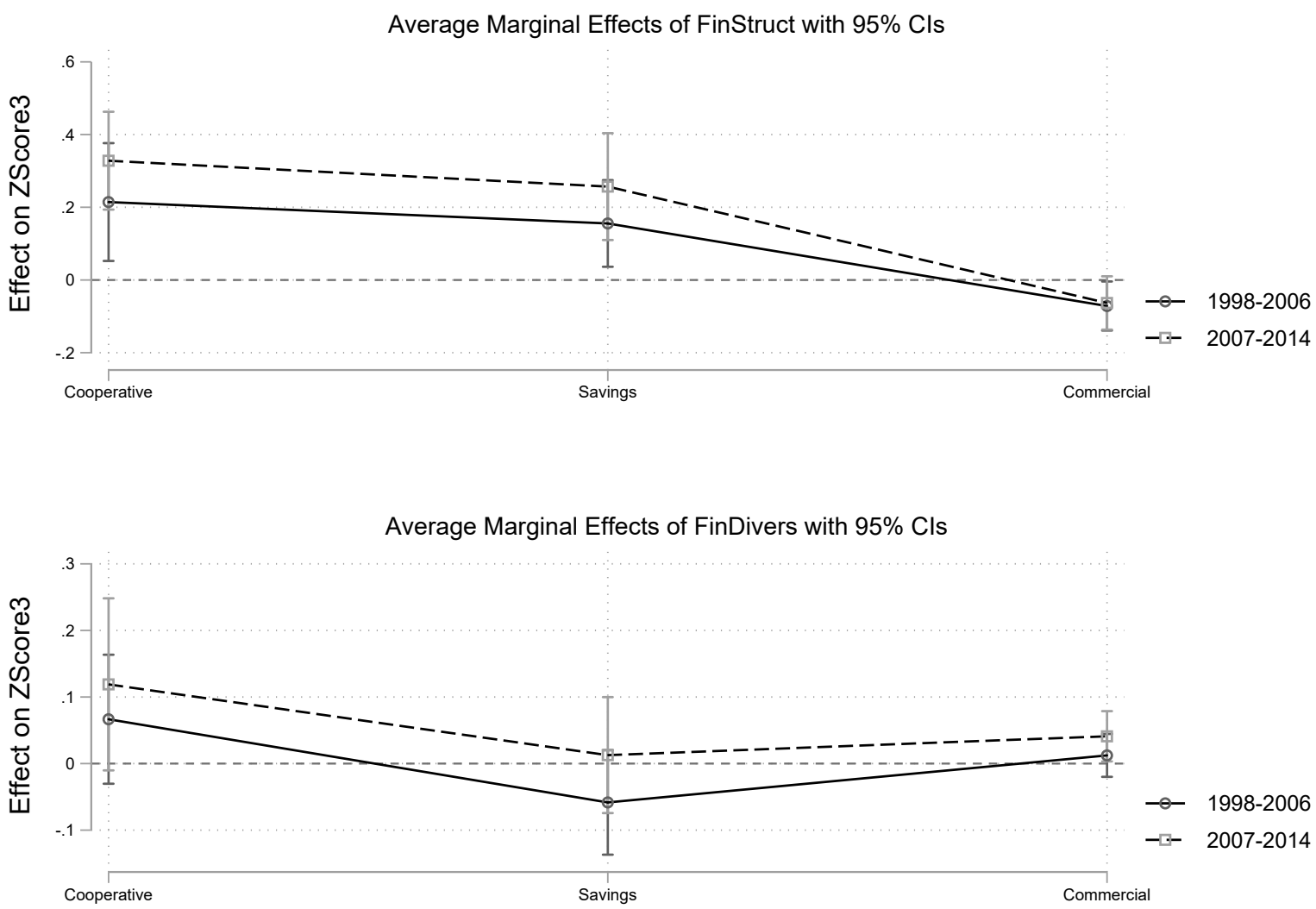

Note: The Figure plots the marginal effects of the two institutional diversity measures, FinStruct (top panel) and FinDivers (bottom panel) on banking sector stability, measured by the Z-Score3 (95\% confidence interval). The marginal effects are computed from the coefficients of Equation [2), estimated with panel techniques and with the full set of controls. The coefficients are separately reported for different bank types (cooperative, saving and commercial banks) and for different subsamples (pre-2007 and post-2007). At the $95 \%$ confidence interval, the coefficients of FinStruct (1998-2006) are statistically different from the one for 2007-2014 for savings banks but not for commercial and cooperative banks. At the 95\% confidence interval, the coefficients of FinDivers (1998-2006) are statistically different from the one for 2007-2014 for commercial banks but not for cooperative and savings banks (see Table7). 
Figure 6: The Impact of Size, Asset Growth and Lerner Index on the FinStruct-Z-Score3Relationship

\section{Effects of standardized bank size on FinStruct}
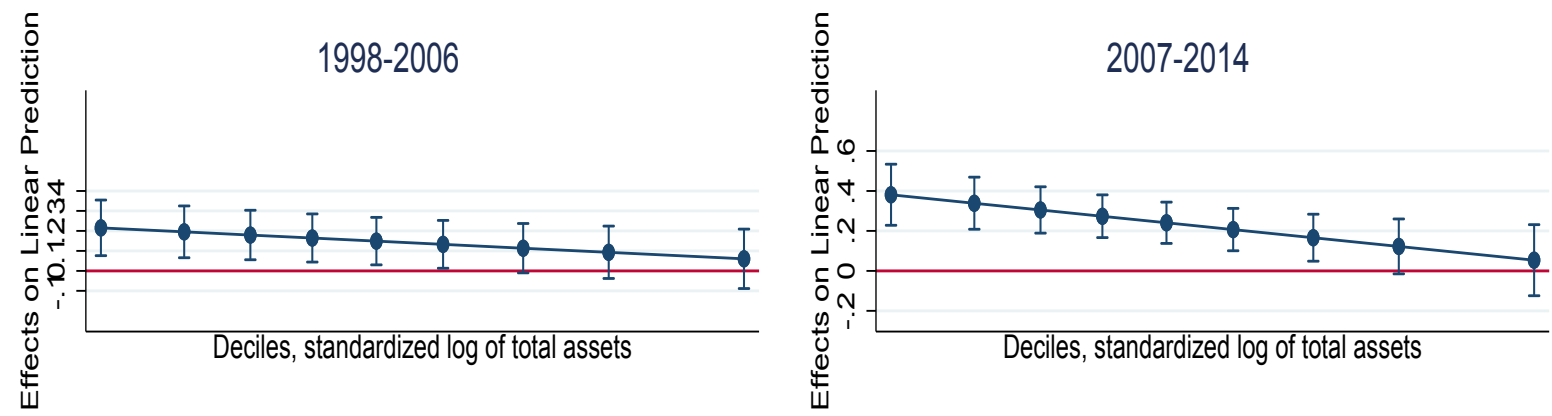

Effects of standardized growth on FinStruct
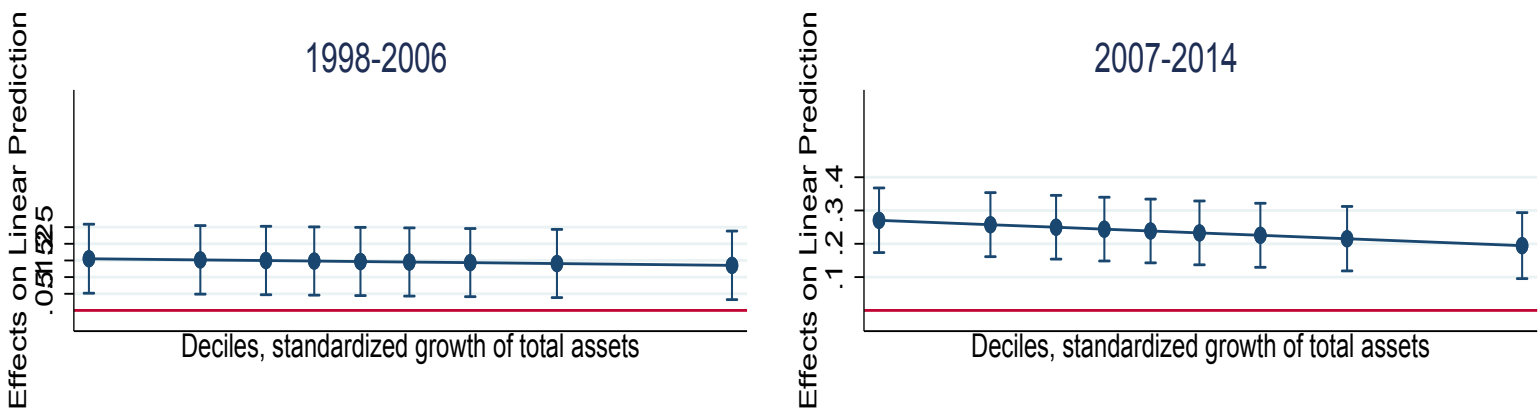

\section{Effects of standardized Lerner Index on FinStruct}
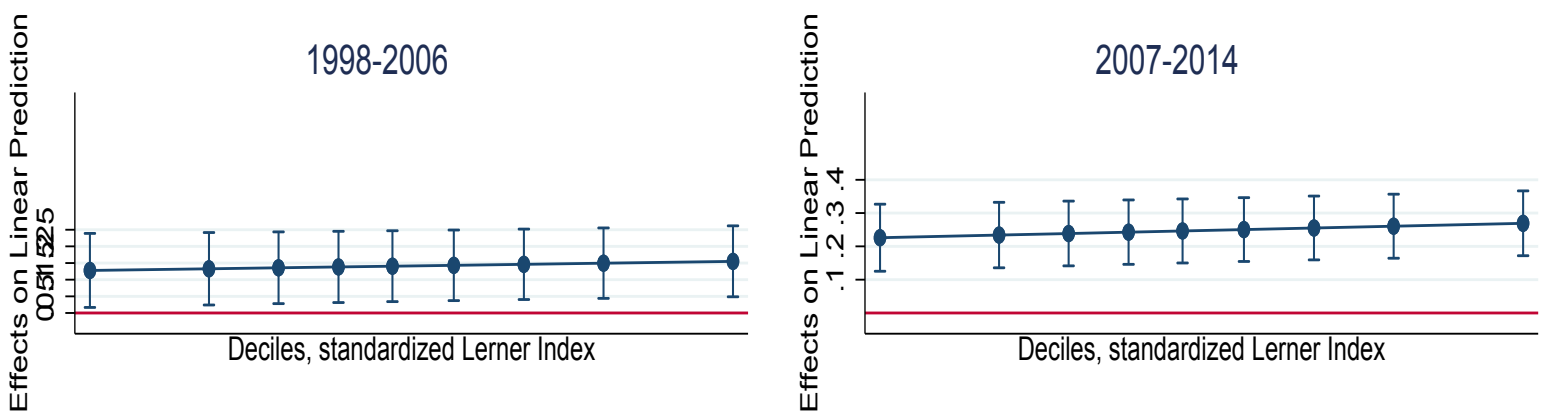

Note: The Figure plots the effect of institutional diversity, captured by FinStruct on banking sector stability, measured by Z-Score3, at different deciles of the distribution of banks' size (top panel), of banks' growth (middle panel) and of the Lerner Index (bottom panel). The reported coefficients are the average marginal effects calculated after estimating Equation 2, 95\% confidence intervals. 
Figure 7: The Impact of Size, Asset Growth and Lerner Index on the FinDivers-Z-Score3 Relationship

\section{Effects of standardized size on FinDivers}
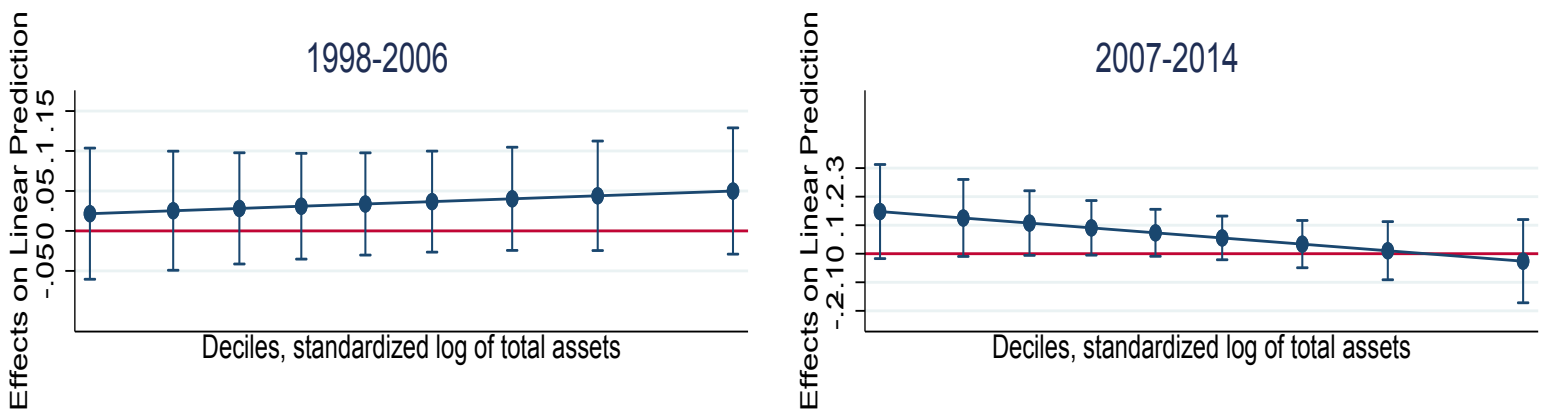

Effects of standardized growth on FinDivers
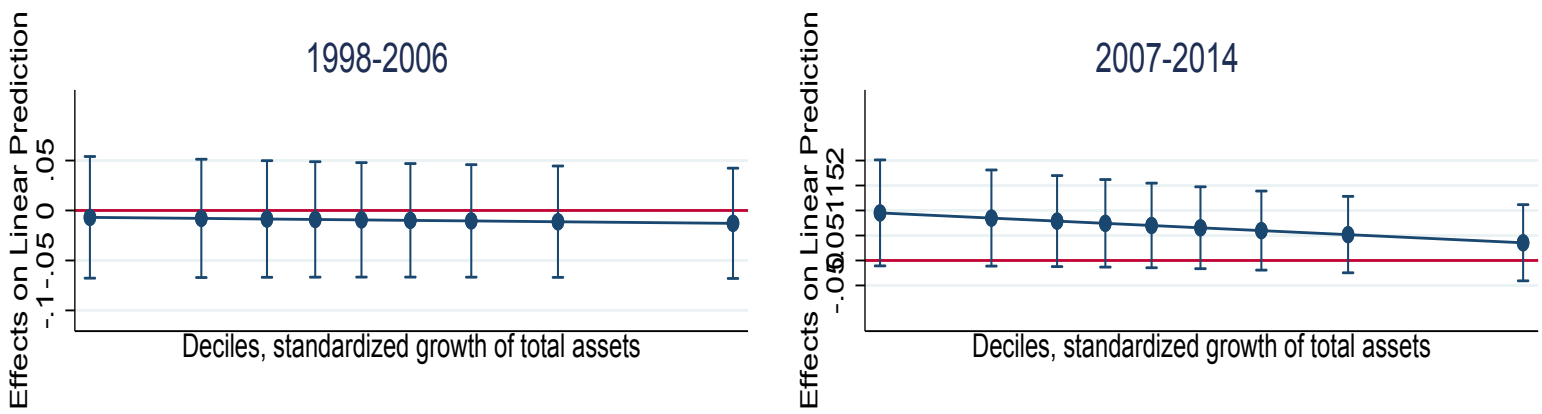

Effects of Lerner Index on FinDivers
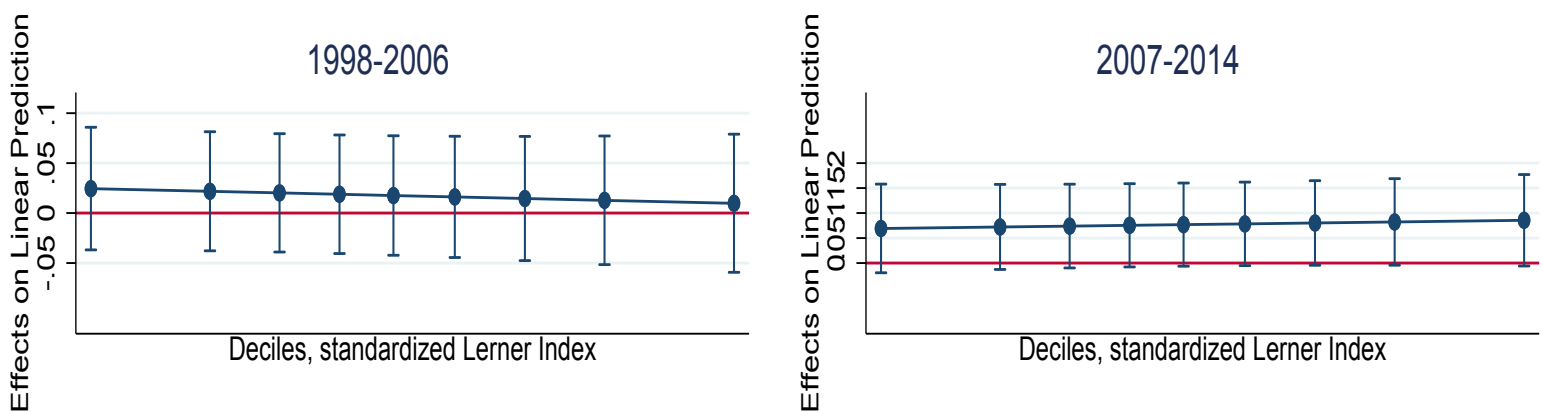

Note: The Figure plots the effect of institutional diversity, captured by FinDivers on banking sector stability, measured by Z-Score3, at different deciles of the distribution of banks' size (top panel), of banks' asset growth (middle panel) and of the Lerner Index (bottom panel), for the full sample. The reported coefficients are the average marginal effects calculated after estimating Equation (2), 95\% confidence intervals. 
Table 8: Institutional Diversity Effects on the Volatility of ROA (ROA Risk), Pre and Post-2007

\begin{tabular}{|c|c|c|c|c|c|c|}
\hline & $\begin{array}{c}\text { (1) } \\
\text { ROA Risk } \\
\text { Full Sample }\end{array}$ & $\begin{array}{c}(2) \\
\text { ROA Risk } \\
\text { 1998-2006 }\end{array}$ & $\begin{array}{c}\text { (3) } \\
\text { ROA Risk } \\
\text { 2007-2014 }\end{array}$ & $\begin{array}{c}(4) \\
\text { ROA Risk } \\
\text { Full Sample }\end{array}$ & $\begin{array}{c}(5) \\
\text { ROA Risk } \\
\text { 1998-2006 }\end{array}$ & $\begin{array}{c}\text { (6) } \\
\text { ROA Risk } \\
\text { 2007-2014 }\end{array}$ \\
\hline FinStruct & $\begin{array}{c}-0.0646 \\
(-1.28)\end{array}$ & $\begin{array}{c}0.0438 \\
(0.74)\end{array}$ & $\begin{array}{c}-0.170^{* * *} \\
(-2.62)\end{array}$ & & & \\
\hline FinDivers & & & & $\begin{array}{c}-0.100^{*} \\
(-1.90)\end{array}$ & $\begin{array}{c}-0.0146 \\
(-0.27)\end{array}$ & $\begin{array}{c}-0.183^{* * *} \\
(-2.70)\end{array}$ \\
\hline Internal Divers & $\begin{array}{c}0.246^{* *} \\
(1.98)\end{array}$ & $\begin{array}{l}0.0970 \\
(0.79)\end{array}$ & $\begin{array}{c}0.391^{* *} \\
(2.21)\end{array}$ & $\begin{array}{l}0.241^{*} \\
(1.92)\end{array}$ & $\begin{array}{c}0.0681 \\
(0.56)\end{array}$ & $\begin{array}{c}0.408^{* *} \\
(2.28)\end{array}$ \\
\hline Lerner Index & $\begin{array}{c}-0.0556^{* * *} \\
(-2.93)\end{array}$ & $\begin{array}{c}-0.0659^{* *} \\
(-2.43)\end{array}$ & $\begin{array}{c}-0.0457^{* *} \\
(-2.44)\end{array}$ & $\begin{array}{c}-0.0564^{* * *} \\
(-3.01)\end{array}$ & $\begin{array}{c}-0.0603^{* *} \\
(-2.28)\end{array}$ & $\begin{array}{c}-0.0525^{* * *} \\
(-2.80)\end{array}$ \\
\hline Efficiency & $\begin{array}{c}0.00381 \\
(0.02)\end{array}$ & $\begin{array}{l}0.331 \\
(1.25)\end{array}$ & $\begin{array}{c}-0.313^{*} \\
(-1.80)\end{array}$ & $\begin{array}{c}0.00108 \\
(0.01)\end{array}$ & $\begin{array}{l}0.370 \\
(1.40)\end{array}$ & $\begin{array}{c}-0.356^{* *} \\
(-2.05)\end{array}$ \\
\hline Wholesale Funding & $\begin{array}{l}0.155 \\
(1.16)\end{array}$ & $\begin{array}{l}0.120 \\
(0.85)\end{array}$ & $\begin{array}{l}0.189 \\
(1.06)\end{array}$ & $\begin{array}{l}0.150 \\
(1.07)\end{array}$ & $\begin{array}{l}0.0804 \\
(0.57)\end{array}$ & $\begin{array}{l}0.218 \\
(1.15)\end{array}$ \\
\hline Liquidity & $\begin{array}{c}-0.0140 \\
(-0.14)\end{array}$ & $\begin{array}{l}0.188 \\
(1.37)\end{array}$ & $\begin{array}{r}-0.210^{*} \\
(-1.88)\end{array}$ & $\begin{array}{c}-0.000379 \\
(-0.00)\end{array}$ & $\begin{array}{l}0.156 \\
(1.14)\end{array}$ & $\begin{array}{l}-0.152 \\
(-1.43)\end{array}$ \\
\hline Equity over Liabilities & $\begin{array}{c}0.149^{* * *} \\
(3.72)\end{array}$ & $\begin{array}{c}0.152^{* * *} \\
(3.32)\end{array}$ & $\begin{array}{c}0.146^{* * *} \\
(3.37)\end{array}$ & $\begin{array}{c}0.147^{* * *} \\
(3.65)\end{array}$ & $\begin{array}{c}0.150^{* * *} \\
(3.31)\end{array}$ & $\begin{array}{c}0.143^{* * *} \\
(3.32)\end{array}$ \\
\hline Net Income over Assets & $\begin{array}{c}-0.0928^{* *} \\
(-2.48)\end{array}$ & $\begin{array}{c}0.00114 \\
(0.02)\end{array}$ & $\begin{array}{c}-0.184^{* * *} \\
(-4.18)\end{array}$ & $\begin{array}{c}-0.0922^{* *} \\
(-2.45)\end{array}$ & $\begin{array}{c}0.00370 \\
(0.06)\end{array}$ & $\begin{array}{c}-0.185^{* * *} \\
(-4.22)\end{array}$ \\
\hline Size & $\begin{array}{c}-0.142^{* * *} \\
(-3.95)\end{array}$ & $\begin{array}{c}-0.145^{* * *} \\
(-3.76)\end{array}$ & $\begin{array}{c}-0.139^{* * *} \\
(-3.97)\end{array}$ & $\begin{array}{c}-0.139^{* * *} \\
(-3.92)\end{array}$ & $\begin{array}{c}-0.145^{* * *} \\
(-3.83)\end{array}$ & $\begin{array}{c}-0.133^{* * *} \\
(-3.83)\end{array}$ \\
\hline Asset Growth & $\begin{array}{l}-0.103 \\
(-1.59)\end{array}$ & $\begin{array}{l}0.120 \\
(1.26)\end{array}$ & $\begin{array}{c}-0.319^{* * *} \\
(-3.53)\end{array}$ & $\begin{array}{l}-0.117^{*} \\
(-1.77)\end{array}$ & $\begin{array}{l}0.105 \\
(1.09)\end{array}$ & $\begin{array}{c}-0.331^{* * *} \\
(-3.59)\end{array}$ \\
\hline Sector Size & $\begin{array}{c}0.0308^{* * *} \\
(5.22)\end{array}$ & $\begin{array}{c}0.0373^{* * *} \\
\quad(4.40)\end{array}$ & $\begin{array}{c}0.0246^{* * *} \\
(4.41)\end{array}$ & $\begin{array}{c}0.0302^{* * *} \\
(5.01)\end{array}$ & $\begin{array}{c}0.0391^{* * *} \\
\quad(4.37)\end{array}$ & $\begin{array}{c}0.0216^{* * *} \\
\quad(3.85)\end{array}$ \\
\hline Financial Depth & $\begin{array}{c}-0.0349^{* * *} \\
(-4.87)\end{array}$ & $\begin{array}{c}-0.0401^{* * *} \\
(-4.07)\end{array}$ & $\begin{array}{c}-0.0299^{* * *} \\
(-4.60)\end{array}$ & $\begin{array}{c}-0.0332^{* * *} \\
(-4.58)\end{array}$ & $\begin{array}{c}-0.0408^{* * *} \\
(-3.93)\end{array}$ & $\begin{array}{c}-0.0259^{* * *} \\
(-4.13)\end{array}$ \\
\hline Credit to MarkCap & $\begin{array}{l}0.0280 \\
(1.47)\end{array}$ & $\begin{array}{c}0.000358 \\
(0.02)\end{array}$ & $\begin{array}{c}0.0548^{* *} \\
(2.16)\end{array}$ & $\begin{array}{c}0.0262 \\
(1.35)\end{array}$ & $\begin{array}{c}0.00400 \\
(0.15)\end{array}$ & $\begin{array}{c}0.0477^{*} \\
(1.93)\end{array}$ \\
\hline Inflation & $\begin{array}{c}0.0428 \\
(1.45)\end{array}$ & $\begin{array}{c}0.0642 \\
(1.40)\end{array}$ & $\begin{array}{l}0.0221 \\
(0.67)\end{array}$ & $\begin{array}{c}0.0470 \\
(1.62)\end{array}$ & $\begin{array}{c}0.0544 \\
(1.21)\end{array}$ & $\begin{array}{c}0.0398 \\
(1.21)\end{array}$ \\
\hline Bank FE & yes & yes & yes & yes & yes & yes \\
\hline Year FE & yes & yes & yes & yes & yes & yes \\
\hline Observations & 38729 & 19059 & 19670 & 38729 & 19059 & 19670 \\
\hline
\end{tabular}

Note: The Table reports the average marginal effects (AME) for FinStruct and FinDivers and the other covariates. The dependent variable is ROA Risk which is the standardized standard deviation of the 3-year rolling ROA. The AME for the variables is obtained by evaluating for each observation an $\varepsilon$-change in FinStruct, FinDivers and the other covariates, computing the derivative of ROA Risk with respect to the covariates and then averaging over the total of observations. Columns 1 and 4 report results for the full sample; Columns 2 and 5 shows results for the pre-2007 subsample (from 1998 to 2006); finally, Columns 3 and 6 contain results for the post-2007 subsample (from 2007 to 2014). Standard errors (in parenthesis) are clustered at the country-year level. The pre-2007 and the post-2007 coefficients for FinStruct (Columns 2 and 3) are statistically different from each other. The same is true for the pre-2007 and the post-2007 coefficients for FinDivers. Significance levels: ${ }^{*} p<0.1,{ }^{* *} p<0.05,{ }^{* * *} p<0.01$. 
Figure 8: Institutional Diversity Effects on the Volatility of ROA (ROA Risk) by Bank Type, Pre and Post-2007
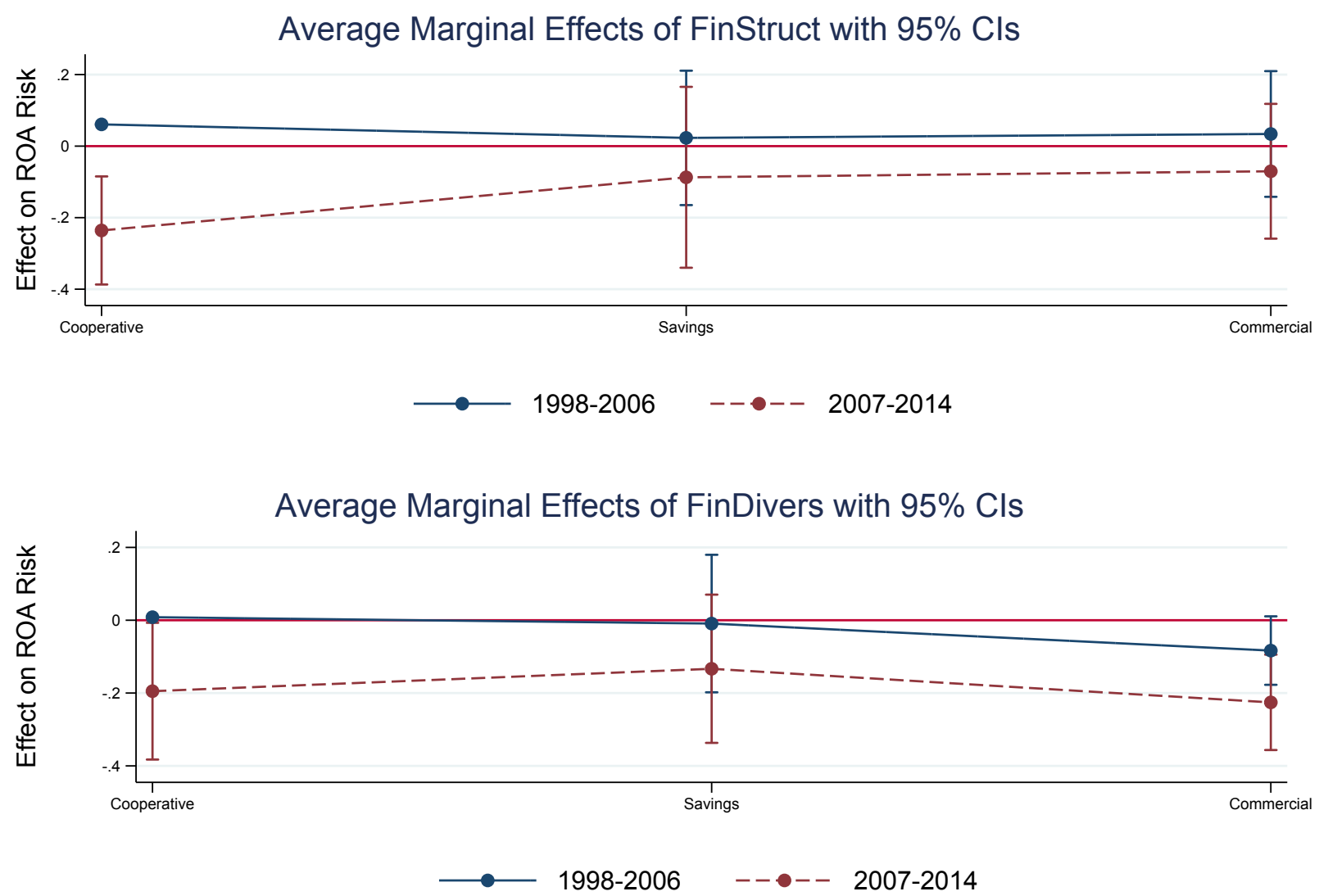

Note: The Figure plots the marginal effects of the two institutional diversity measures, FinStruct (top panel) and FinDivers (bottom panel) on the ROA Risk, measured by the 3-year rolling standard deviation of the ROA. The marginal effects are computed from the coefficients of Equation (2) with ROA Risk as standardized dependent variable, estimated with panel techniques and with the full set of controls. The coefficients are separately reported for different bank types (cooperative, saving and commercial banks) and for different subsamples (1998-2006 and 2007-2014). The coefficients for FinStruct and FinDivers (1998-2006) are statistically different from those for FinStruct and FinDivers (2007-2014), respectively, for cooperative and commercial but not for saving banks ( $95 \%$ confidence intervals). 
Table 9: Institutional Diversity Effects on Bank Stability, Robustness Check with Acute Crisis

\begin{tabular}{|c|c|c|c|c|c|c|}
\hline & $\begin{array}{c}(1) \\
\text { Z-Score3 } \\
\text { Full Sample }\end{array}$ & $\begin{array}{c}(2) \\
\text { Z-Score3 } \\
\text { No Crisis }\end{array}$ & $\begin{array}{c}\text { (3) } \\
\text { Z-Score3 } \\
\text { Acute Crisis }\end{array}$ & $\begin{array}{c}(4) \\
\text { Z-Score3 } \\
\text { Full Sample }\end{array}$ & $\begin{array}{c}\text { (5) } \\
\text { Z-Score3 } \\
\text { No Crisis }\end{array}$ & $\begin{array}{c}\text { (6) } \\
\text { Z-Score3 } \\
\text { Acute Crisis }\end{array}$ \\
\hline FinStruct & $\begin{array}{c}0.201^{* * *} \\
(3.89)\end{array}$ & $\begin{array}{c}0.169^{* * *} \\
(3.13)\end{array}$ & $\begin{array}{c}0.225^{* * *} \\
(4.19)\end{array}$ & & & \\
\hline FinDivers & & & & $\begin{array}{c}0.0912^{* * *} \\
(3.22)\end{array}$ & $\begin{array}{c}0.0453 \\
(1.47)\end{array}$ & $\begin{array}{c}0.127^{* * *} \\
(3.81)\end{array}$ \\
\hline Internal Divers & $\begin{array}{c}-0.180^{*} \\
(-1.79)\end{array}$ & $\begin{array}{l}-0.112 \\
(-1.16)\end{array}$ & $\begin{array}{c}-0.233^{*} \\
(-1.72)\end{array}$ & $\begin{array}{c}-0.188^{*} \\
(-1.91)\end{array}$ & $\begin{array}{c}-0.0797 \\
(-0.83)\end{array}$ & $\begin{array}{c}-0.273^{* *} \\
(-2.05)\end{array}$ \\
\hline Lerner Index & $\begin{array}{c}0.0332^{* *} \\
(2.05)\end{array}$ & $\begin{array}{c}0.00585 \\
(0.42)\end{array}$ & $\begin{array}{c}0.0546^{* *} \\
(2.51)\end{array}$ & $\begin{array}{c}0.0337^{* *} \\
(2.04)\end{array}$ & $\begin{array}{c}0.00225 \\
(0.16)\end{array}$ & $\begin{array}{c}0.0581^{* * *} \\
(2.58)\end{array}$ \\
\hline Efficiency & $\begin{array}{c}0.0320 \\
(0.28)\end{array}$ & $\begin{array}{l}-0.100 \\
(-0.88)\end{array}$ & $\begin{array}{l}0.135 \\
(0.97)\end{array}$ & $\begin{array}{c}0.00858 \\
(0.07)\end{array}$ & $\begin{array}{l}-0.181 \\
(-1.56)\end{array}$ & $\begin{array}{l}0.156 \\
(1.07)\end{array}$ \\
\hline Wholesale Funding & $\begin{array}{c}-0.0877 \\
(-1.03)\end{array}$ & $\begin{array}{c}-0.207^{* *} \\
(-2.07)\end{array}$ & $\begin{array}{c}0.00541 \\
(0.05)\end{array}$ & $\begin{array}{l}-0.124 \\
(-1.37)\end{array}$ & $\begin{array}{c}-0.306^{* * *} \\
(-2.80)\end{array}$ & $\begin{array}{c}0.0172 \\
(0.15)\end{array}$ \\
\hline Liquidity & $\begin{array}{c}0.0705 \\
(0.67)\end{array}$ & $\begin{array}{l}0.151 \\
(1.62)\end{array}$ & $\begin{array}{c}0.00753 \\
(0.05)\end{array}$ & $\begin{array}{c}0.0542 \\
(0.52)\end{array}$ & $\begin{array}{c}0.152^{*} \\
(1.69)\end{array}$ & $\begin{array}{c}-0.0219 \\
(-0.15)\end{array}$ \\
\hline Equity over Liabilities & $\begin{array}{c}0.149^{* * *} \\
(5.01)\end{array}$ & $\begin{array}{c}0.125^{* * *} \\
(4.65)\end{array}$ & $\begin{array}{c}0.168^{* * *} \\
(4.66)\end{array}$ & $\begin{array}{c}0.162^{* * *} \\
(5.51)\end{array}$ & $\begin{array}{c}0.129^{* * *} \\
(4.68)\end{array}$ & $\begin{array}{c}0.188^{* * *} \\
(5.39)\end{array}$ \\
\hline Net Income over Assets & $\begin{array}{c}0.000415 \\
(0.03)\end{array}$ & $\begin{array}{c}-0.0122 \\
(-0.64)\end{array}$ & $\begin{array}{c}0.0103 \\
(0.54)\end{array}$ & $\begin{array}{c}0.00117 \\
(0.08)\end{array}$ & $\begin{array}{c}-0.0164 \\
(-0.87)\end{array}$ & $\begin{array}{c}0.0148 \\
(0.77)\end{array}$ \\
\hline Size & $\begin{array}{c}0.0391^{*} \\
(1.66)\end{array}$ & $\begin{array}{c}0.0404^{*} \\
(1.85)\end{array}$ & $\begin{array}{c}0.0380 \\
(1.46)\end{array}$ & $\begin{array}{c}0.0395^{*} \\
(1.72)\end{array}$ & $\begin{array}{c}0.0415^{*} \\
(1.93)\end{array}$ & $\begin{array}{c}0.0378 \\
(1.48)\end{array}$ \\
\hline Asset Growth & $\begin{array}{c}-0.633^{* * *} \\
(-11.17)\end{array}$ & $\begin{array}{c}-0.514^{* * *} \\
(-6.87)\end{array}$ & $\begin{array}{c}-0.726^{* * *} \\
(-11.06)\end{array}$ & $\begin{array}{c}-0.612^{* * *} \\
(-11.23)\end{array}$ & $\begin{array}{c}-0.546^{* * *} \\
(-8.14)\end{array}$ & $\begin{array}{c}-0.664^{* * *} \\
(-10.01)\end{array}$ \\
\hline Sector Size & $\begin{array}{c}-0.0175^{* * *} \\
(-5.87)\end{array}$ & $\begin{array}{c}-0.0153^{* * *} \\
(-4.14)\end{array}$ & $\begin{array}{c}-0.0193^{* * *} \\
(-6.06)\end{array}$ & $\begin{array}{c}-0.0164^{* * *} \\
(-4.59)\end{array}$ & $\begin{array}{c}-0.0136^{* * *} \\
(-3.29)\end{array}$ & $\begin{array}{c}-0.0187^{* * *} \\
(-4.75)\end{array}$ \\
\hline Financial Depth & $\begin{array}{c}0.0164^{* * *} \\
(4.79)\end{array}$ & $\begin{array}{c}0.0136^{* * *} \\
(3.14)\end{array}$ & $\begin{array}{c}0.0186^{* * *} \\
(5.39)\end{array}$ & $\begin{array}{c}0.0129^{* * *} \\
(3.02)\end{array}$ & $\begin{array}{c}0.00986^{* *} \\
(2.00)\end{array}$ & $\begin{array}{c}0.0152^{* * *} \\
(3.33)\end{array}$ \\
\hline Credit to MarkCap & $\begin{array}{c}-0.0351^{* * *} \\
(-3.06)\end{array}$ & $\begin{array}{c}-0.00386 \\
(-0.33)\end{array}$ & $\begin{array}{c}-0.0595^{* * *} \\
(-3.96)\end{array}$ & $\begin{array}{c}-0.0148 \\
(-1.46)\end{array}$ & $\begin{array}{c}0.0113 \\
(1.03)\end{array}$ & $\begin{array}{c}-0.0352^{* *} \\
(-2.54)\end{array}$ \\
\hline Inflation & $\begin{array}{c}0.0297^{* * *} \\
(2.92)\end{array}$ & $\begin{array}{c}0.0324^{* *} \\
(2.39)\end{array}$ & $\begin{array}{c}0.0275^{* *} \\
(2.15)\end{array}$ & $\begin{array}{c}0.0225^{* *} \\
(2.04)\end{array}$ & $\begin{array}{c}0.0273^{* *} \\
(1.97)\end{array}$ & $\begin{array}{c}0.0188 \\
(1.37)\end{array}$ \\
\hline Bank FE & yes & yes & yes & yes & yes & yes \\
\hline Year FE & yes & yes & yes & yes & yes & yes \\
\hline Observations & 38729 & 16957 & 21772 & 38729 & 16957 & 21772 \\
\hline
\end{tabular}

Note: The Table shows the Avarage Marginal Effect (AME) for FinStruct and FinDivers, and the other covariates. The dependent variable is Z-Score3. The average effect for the variables is obtained by evaluating for each observation an $\epsilon$ change in FinStruct, FinDivers and the other covariates, computing the derivative of Z-Score 3 with respect to the covariates and then averaging over the total of observations. Columns 1 and 4 report results for the full sample; Columns 2 and 5 shows results for No Crisis years; finally, Columns 3 and 6 contain results for the Acute Crisis-subsample. Standard errors (in parenthesis) are clustered at the country-year level. The coefficients of the diversity indicators in Column (2) and (5) are statistically different from the coefficient in Column (3) and (6), respectively. Significance levels: ${ }^{*} p<0.1,{ }^{* *} p<0.05,{ }^{* * *}$ $p<0.01$. 
Figure 9: Institutional Diversity Effects on Bank Stability by Bank Types - Robustness Check with AcuteCrisis
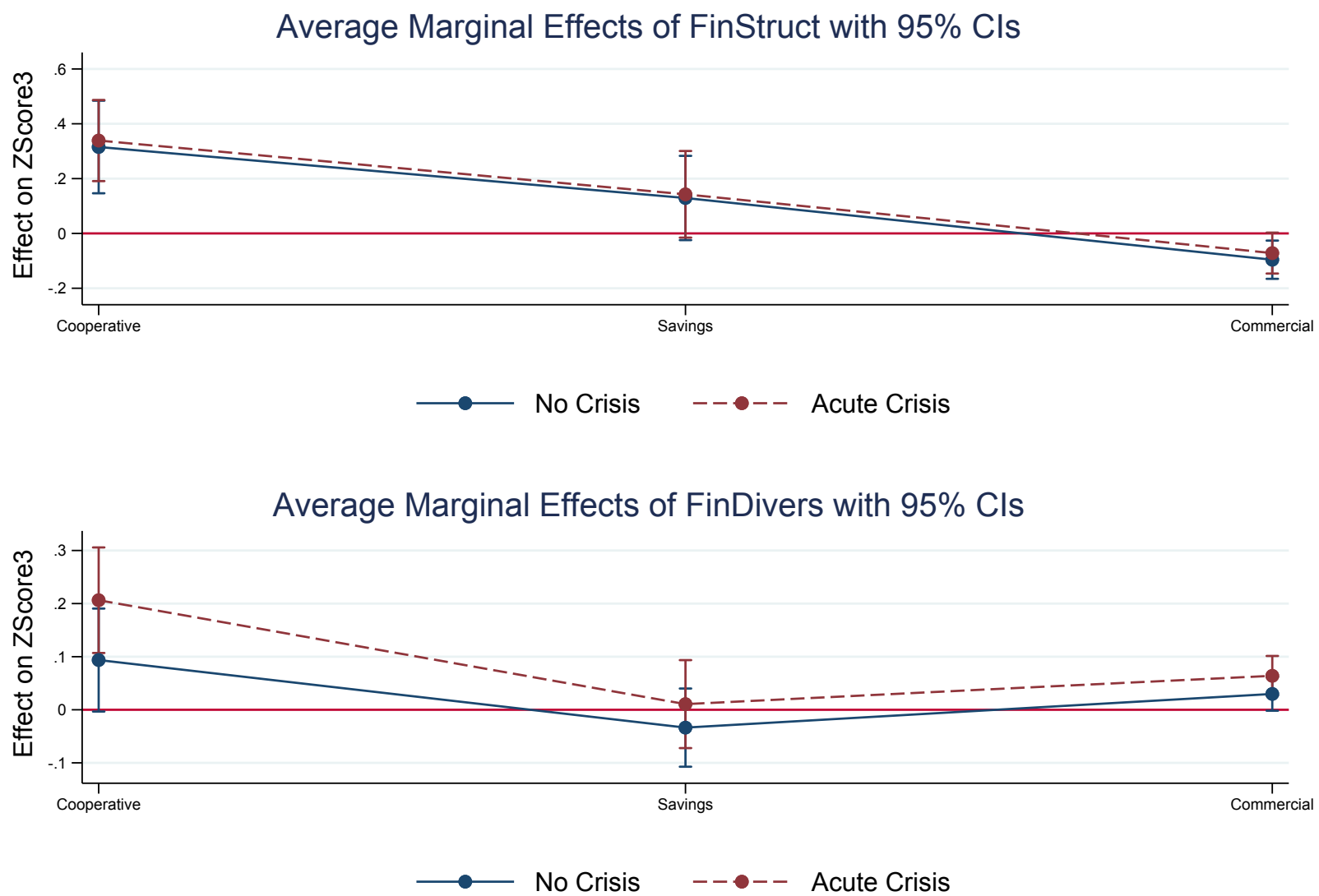

Note: The Figure plots the marginal effects of two banking sector diversity measures, FinStruct (top panel) and FinDivers (bottom panel) on banking sector stabiliy, measured by Z-Score3. The marginal effects are computed from the coefficients of Equation (2), estimated with panel techniques and with the full set of controls. The coefficients and confidence intervals are separately reported for different bank types (cooperative, saving and commercial banks) and for different subsamples (No Crisis and Acute Crisis), 95\% confidence intervals. 
Table 10: Institutional Diversity Effects on Bank Stability - Robustness Check with Z-Score5

\begin{tabular}{|c|c|c|c|c|c|c|}
\hline & $\begin{array}{c}\text { (1) } \\
\text { Z-Score5 } \\
\text { Full Sample }\end{array}$ & $\begin{array}{c}(2) \\
\text { Z-Score5 } \\
\text { 1998-2006 }\end{array}$ & $\begin{array}{c}\text { (3) } \\
\text { Z-Score5 } \\
\text { 2007-2014 }\end{array}$ & $\begin{array}{c}\text { (4) } \\
\text { Z-Score5 } \\
\text { Full Sample }\end{array}$ & $\begin{array}{c}(5) \\
\text { Z-Score5 } \\
1998-2006\end{array}$ & $\begin{array}{c}(6) \\
\text { Z-Score5 } \\
2007-2014\end{array}$ \\
\hline FinStruct & $\begin{array}{c}0.304^{* * *} \\
(5.24)\end{array}$ & $\begin{array}{c}0.232^{* * *} \\
(3.67)\end{array}$ & $\begin{array}{c}0.372^{* * *} \\
(5.92)\end{array}$ & & & \\
\hline FinDivers & & & & $\begin{array}{c}0.0586 \\
(1.58)\end{array}$ & $\begin{array}{c}0.00691 \\
(0.23)\end{array}$ & $\begin{array}{c}0.108^{* *} \\
(1.99)\end{array}$ \\
\hline Internal Divers & $\begin{array}{c}-0.134^{*} \\
(-1.82)\end{array}$ & $\begin{array}{c}0.0501 \\
(0.64)\end{array}$ & $\begin{array}{c}-0.311^{* * *} \\
(-2.65)\end{array}$ & $\begin{array}{c}-0.161^{* *} \\
(-2.21)\end{array}$ & $\begin{array}{c}0.0225 \\
(0.28)\end{array}$ & $\begin{array}{c}-0.338^{* * *} \\
(-2.92)\end{array}$ \\
\hline Lerner Index & $\begin{array}{c}0.0356^{* *} \\
(2.26)\end{array}$ & $\begin{array}{c}0.0213 \\
(1.42)\end{array}$ & $\begin{array}{c}0.0495^{* *} \\
(2.21)\end{array}$ & $\begin{array}{c}0.0356^{* *} \\
(2.21)\end{array}$ & $\begin{array}{c}0.0217 \\
(1.44)\end{array}$ & $\begin{array}{c}0.0491^{* *} \\
(2.12)\end{array}$ \\
\hline Efficiency & $\begin{array}{c}0.0343 \\
(0.38)\end{array}$ & $\begin{array}{c}-0.0215 \\
(-0.21)\end{array}$ & $\begin{array}{c}0.0881 \\
(0.74)\end{array}$ & $\begin{array}{c}0.0163 \\
(0.18)\end{array}$ & $\begin{array}{c}-0.0635 \\
(-0.61)\end{array}$ & $\begin{array}{c}0.0931 \\
(0.78)\end{array}$ \\
\hline Wholesale Funding & $\begin{array}{c}-0.313^{* * *} \\
(-3.25)\end{array}$ & $\begin{array}{l}-0.112 \\
(-0.80)\end{array}$ & $\begin{array}{c}-0.507^{* * *} \\
(-4.21)\end{array}$ & $\begin{array}{c}-0.369^{* * *} \\
(-3.69)\end{array}$ & $\begin{array}{l}-0.184 \\
(-1.32)\end{array}$ & $\begin{array}{c}-0.546^{* * *} \\
(-4.29)\end{array}$ \\
\hline Liquidity & $\begin{array}{c}-0.0255 \\
(-0.25)\end{array}$ & $\begin{array}{l}0.137 \\
(1.43)\end{array}$ & $\begin{array}{l}-0.182 \\
(-1.35)\end{array}$ & $\begin{array}{c}-0.0623 \\
(-0.63)\end{array}$ & $\begin{array}{l}0.139 \\
(1.53)\end{array}$ & $\begin{array}{c}-0.256^{*} \\
(-1.88)\end{array}$ \\
\hline Equity over Liabilities & $\begin{array}{c}0.225^{* * *} \\
(7.71)\end{array}$ & $\begin{array}{c}0.211^{* * *} \\
(7.56)\end{array}$ & $\begin{array}{c}0.240^{* * *} \\
(6.64)\end{array}$ & $\begin{array}{c}0.259^{* * *} \\
(8.61)\end{array}$ & $\begin{array}{c}0.254^{* * *} \\
(8.84)\end{array}$ & $\begin{array}{c}0.264^{* * *} \\
(7.25)\end{array}$ \\
\hline Net Income over Assets & $\begin{array}{c}-0.000100 \\
(-0.01)\end{array}$ & $\begin{array}{c}0.0131 \\
(0.63)\end{array}$ & $\begin{array}{c}-0.0128 \\
(-0.57)\end{array}$ & $\begin{array}{c}-0.00268 \\
(-0.17)\end{array}$ & $\begin{array}{c}0.0112 \\
(0.54)\end{array}$ & $\begin{array}{c}-0.0160 \\
(-0.71)\end{array}$ \\
\hline Size & $\begin{array}{c}0.0462 \\
(1.34)\end{array}$ & $\begin{array}{c}0.0107 \\
(0.30)\end{array}$ & $\begin{array}{c}0.0805^{* *} \\
(2.24)\end{array}$ & $\begin{array}{c}0.0500 \\
(1.46)\end{array}$ & $\begin{array}{c}0.0175 \\
(0.49)\end{array}$ & $\begin{array}{c}0.0813^{* *} \\
(2.28)\end{array}$ \\
\hline Asset Growth & $\begin{array}{c}-0.144^{* * *} \\
(-2.84)\end{array}$ & $\begin{array}{c}-0.209^{* * *} \\
(-5.16)\end{array}$ & $\begin{array}{c}-0.0806 \\
(-0.92)\end{array}$ & $\begin{array}{c}-0.108^{* *} \\
(-2.10)\end{array}$ & $\begin{array}{c}-0.180^{* * *} \\
(-3.97)\end{array}$ & $\begin{array}{c}-0.0387 \\
(-0.45)\end{array}$ \\
\hline Sector Size & $\begin{array}{c}-0.0182^{\text {*** }} \\
(-4.25)\end{array}$ & $\begin{array}{c}-0.0181^{* * *} \\
(-2.90)\end{array}$ & $\begin{array}{c}-0.0182^{* * *} \\
(-4.90)\end{array}$ & $\begin{array}{c}-0.0207^{* * *} \\
(-4.13)\end{array}$ & $\begin{array}{c}-0.0235^{* * *} \\
(-3.29)\end{array}$ & $\begin{array}{c}-0.0180^{* * *} \\
(-3.59)\end{array}$ \\
\hline Financial Depth & $\begin{array}{c}0.0153^{* * *} \\
(3.10)\end{array}$ & $\begin{array}{c}0.0167^{* *} \\
(2.30)\end{array}$ & $\begin{array}{c}0.0139^{* * *} \\
(3.48)\end{array}$ & $\begin{array}{c}0.0156^{* * *} \\
(2.67)\end{array}$ & $\begin{array}{c}0.0201^{* *} \\
(2.43)\end{array}$ & $\begin{array}{c}0.0113^{* *} \\
(2.05)\end{array}$ \\
\hline Credit to MarkCap & $\begin{array}{c}-0.0348^{* *} \\
(-2.22)\end{array}$ & $\begin{array}{c}0.000244 \\
(0.02)\end{array}$ & $\begin{array}{c}-0.0685^{* * *} \\
(-2.73)\end{array}$ & $\begin{array}{c}-0.0160 \\
(-1.11)\end{array}$ & $\begin{array}{c}0.0141 \\
(1.22)\end{array}$ & $\begin{array}{c}-0.0451^{*} \\
(-1.89)\end{array}$ \\
\hline Inflation & $\begin{array}{c}0.0196 \\
(1.41) \\
\end{array}$ & $\begin{array}{c}-0.00141 \\
(-0.08)\end{array}$ & $\begin{array}{c}0.0398^{* *} \\
(2.13) \\
\end{array}$ & $\begin{array}{c}0.0103 \\
(0.67) \\
\end{array}$ & $\begin{array}{c}-0.0277 \\
(-1.64) \\
\end{array}$ & $\begin{array}{c}0.0469^{* *} \\
(2.11) \\
\end{array}$ \\
\hline Bank FE & yes & yes & yes & yes & yes & yes \\
\hline Year FE & yes & yes & yes & yes & yes & yes \\
\hline Observations & 38135 & 18713 & 19422 & 38135 & 18713 & 19422 \\
\hline
\end{tabular}

Note: The Table reports the average marginal effects (AME) for FinStruct and FinDivers and the other covariates. The dependent variable is Z-Score5. Columns 1 and 4 report results for the full sample; Columns 2 and 5 shows results for the pre-2007 subsample (from 1998 to 2006); finally, Columns 3 and 6 contain results for the post-2007 subsample (from 2007 to 2014). Standard errors (in parenthesis) are clustered at the country-year level. Significance levels: * $p<0.1,{ }^{* *} p<0.05,{ }^{* * *} p<0.01$. 
Figure 10: Institutional Diversity Effects on Bank Stability by Bank Type, Robustness Check with Z-Score5
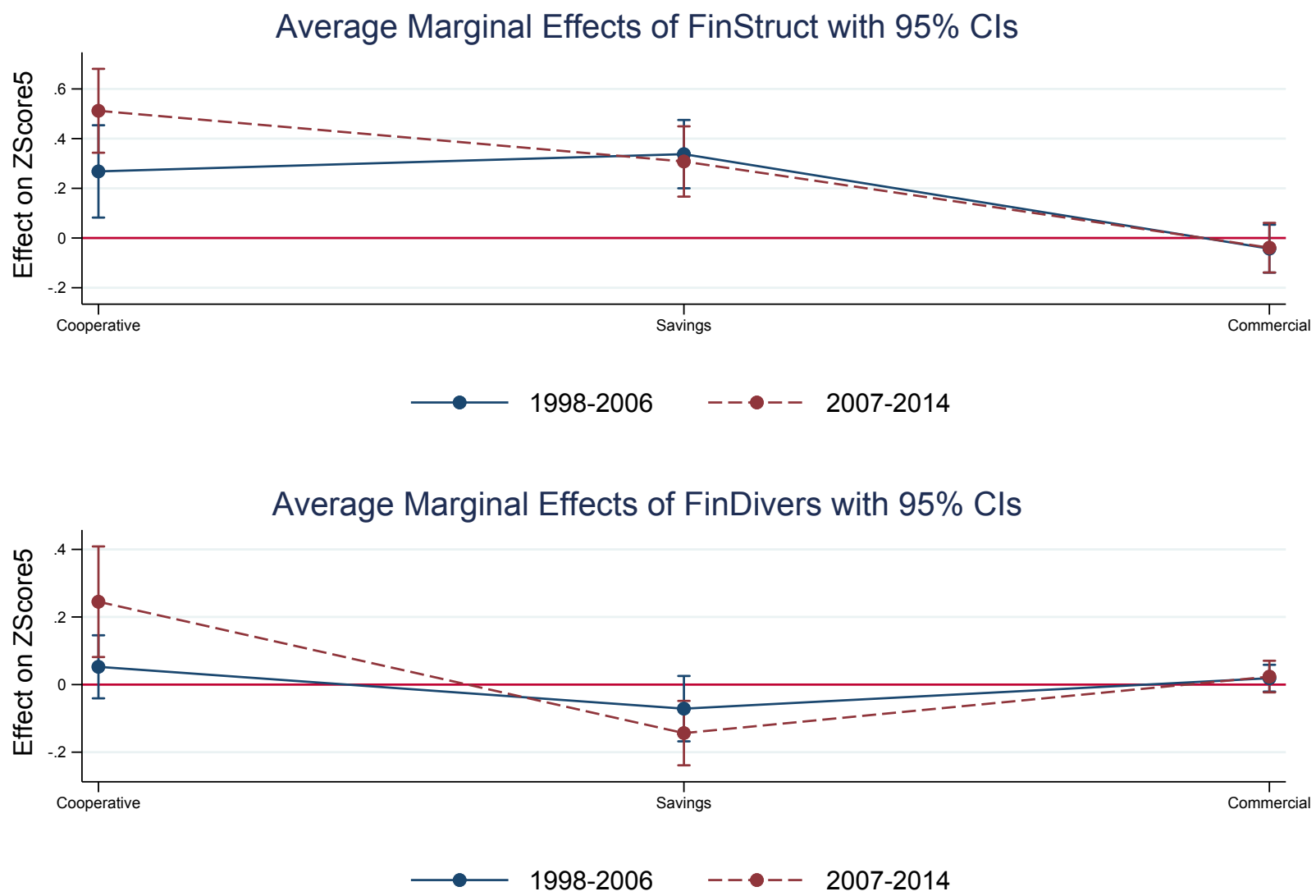

Note: The Figure plots the marginal effects of two banking sector diversity measures, FinStruct (top panel) and FinDivers (bottom panel ) on banking sector stabiliy, measured by Z-Score5. The marginal effects are computed from the coefficients of Equation (2), estimated with panel techniques and with the full set of controls. The coefficients are separately reported for different bank types (cooperative, saving and commercial banks) and for different subsamples (pre-2007 and post-2007), 95\% confidence intervals. 